\title{
LEITURA DOS PAINÉIS FIGURATIVOS HISTORIADOS DE AZULEJOS DOS CONVENTOS FRANCISCANOS DE OLINDA E DO RECIFE DOS SÉCULOS XVII E XVIII
}

Jaqueline de Lima da Silva*

Suely Cisneiros Muniz ${ }^{* *}$
RESUMO: A partir do estudo dos azulejos que ornamentam os Conventos Franciscanos de Olinda e do Recife, ambos dos séculos XVII e XVIII, torna-se possível compreender como este bem, que integra o patrimônio cultural brasileiro, destaca-se por seus valores histórico e estético e, como é notável a dificuldade na leitura total ou parcial de determinados painéis figurativos historiados. Desta forma, analisam-se as condições atuais dos painéis com relação às interferências naturais e/ou antrópicas na busca da identificação das situações que impossibilitam tal leitura.

Palavras-chave: Painéis de Azulejos, Conventos Franciscanos, Leitura de Painéis Azulejares, Azulejaria Portuguesa.

ABSTRACT: From the study of the tiles that adorn the Franciscan Convents of Olinda and Recife, both from the 17th and 18th centuries, it becomes possible to understand how this good, that integrates the Brazilian cultural heritage, stands out for its historical and aesthetic values and how remarkable is the difficulty in the total or partial reading of certain figurative panels historian. Thus, the current conditions of the panels with respect to natural and/or anthropic interference are analyzed in the search for the identification of the situations that make it impossible reading.

Keywords: Panels Tiles, Franciscans Convents, Reading Panels Azulejares, Portuguese Tiles. 


\section{Introdução}

Pernambuco ocupa um lugar peculiar na história do Brasil. Desde o primeiro século de colonização é onde se encontram as mais antigas manifestações artísticas que expressam as tradições portuguesas trazidas para o estado. Nas suas igrejas, conventos e edifícios civis ficaram exemplares que comprovam o gosto por essa arte, a exemplo dos Conventos Franciscanos de Olinda e do Recife.

Desde o primeiro quartel do século XVII até o último do século XVIII, Pernambuco recebeu o que era verdadeiramente representativo da azulejaria portuguesa, ostentando um acervo com excelentes exemplos de cada período.

A admiração pessoal por essa arte, pela estética que confere às estruturas nas quais está integrado de forma tão harmoniosa, foram fatores determinantes para a escolha do tema. Decidimos estudar os painéis figurativos historiados de azulejos dos referidos conventos por possuírem um acervo significativo que pode ser considerado como excelente exemplo de ornamentação azulejar em Pernambuco.

Nesse contexto, considerou-se como objetivos do trabalho: identificar quais as situações que impossibilitam a leitura dos painéis figurativos historiados; analisar a história dos Conventos Franciscanos de Olinda e do Recife sob o ponto de vista do repertório azulejar; entender como a ausência (lacuna) de peças de azulejos descaracteriza a leitura dos painéis e compreender como a subtração de fileiras e colocação aleatória de peças de azulejos em um painel torna impossível sua leitura total ou parcial.

\section{Referencial Teórico}

No âmbito da Arqueologia Histórica o estudo do azulejo está relacionado ao repertório decorativo do espaço da arquitetura e representa a cultura material de uma determinada época. Ressalta-se que, por se tratar de um tema pouco trabalhado até o momento, existe uma escassez de obras literárias abordando a ornamentação azulejar no território brasileiro, todavia encontrou-se algumas produções que proporcionaram o embasamento teórico para a realização desta pesquisa.

Considerado um dos mais importantes pesquisadores da azulejaria portuguesa e brasileira, João Miguel dos Santos Simões, de leitura singular e indispensável, realizou vasta pesquisa ao longo de vários anos com apoio da Fundação Calouste Gulbenkian, de Lisboa. Elaborou um plano de publicações sobre a azulejaria portuguesa resultando no "Corpus" do azulejo português. Entre suas obras destaca-se "Azulejaria portuguesa no Brasil 1500-1822", na qual identifica e analisa o vasto repertório azulejar brasileiro.

Outros autores versaram sobre a azulejaria ao estudar os centros artísticos nos quais ela se faz presente, como o Frei Bonifácio Mueller, que editou "Convento de Santo Antônio do Recife, 1606-1956: esboço histórico", obra resultante da pesquisa sobre a documentação dos arquivos da Ordem Franciscana e de outros acervos de Pernambuco e da Bahia, além dos principais 
arquivos portugueses, entre eles o Arquivo Histórico Ultramarino. Mueller (1956) escreve sobre a fundação do Convento Franciscano do Recife, apresentando os aspectos arquitetônicos e principalmente trazendo uma descrição preciosa acerca das cenas retratadas nos painéis de azulejos.

Jorge Eduardo Lucena Tinoco publica, em 2007, uma rápida retrospectiva sobre as intervenções nos painéis de azulejos dos monumentos localizados em Pernambuco, Paraíba e Alagoas, apontando as principais características e patologias. Propõe recomendações para a elaboração de projetos executivos de conservação e de restauro dos azulejos. A sua obra versa sobre as principais diretrizes, normas, responsabilidades, obrigações e procedimentos para aplicação de técnicas tradicionais nas ações de salvaguarda dos antigos conjuntos azulejares luso-brasileiros.

Em trabalhos mais recentes sobre a azulejaria destaca-se Sylvia Tigre de Hollanda Cavalcanti que editou, em 2002, "O azulejo na arquitetura civil de Pernambuco - século XIX", resgatando o valor arquitetônico e cultural da azulejaria civil pernambucana no cenário da cultura brasileira a partir de mais de 100 padrões originais importados de Portugal, França e Inglaterra que ainda hoje, no século XXI, são encontrados nas fachadas de casarões ou de sobrados, remanescentes em onze cidades pernambucanas, especialmente Recife e Olinda. Além disso, a pesquisadora alerta sobre a extinção do acervo azulejar civil causada pelo abandono por parte dos proprietários, furtos dos exemplares e descaso público. Em 2006, publicou "O azulejo na arquitetura religiosa de Pernambuco - séculos XVII e XVIII", oferecendo aos interessados pela arte e arquitetura desses séculos informações acerca dos valiosos exemplares da azulejaria religiosa que resistiram ao tempo.

Suely Cisneiros Muniz (2009) propôs uma classificação histórica dos revestimentos azulejares e desenvolveu um método de análise das patologias químicas e físicas verificadas em vários edifícios religiosos e civis dos séculos XVII e XVIII em Pernambuco. O método proporcionou um mapeamento de danos da azulejaria conduzindo ao diagnóstico que pode servir de modelo aplicável a edificações semelhantes em outros locais do país.

Em uma coletânea que agrupa e registra, em forma documental, o conteúdo apresentado por técnicos de diversas áreas profissionais, no projeto Oficinas de Estudos da Preservação, desenvolvido pela Superintendência do Iphan no Rio de Janeiro, a pesquisadora Dora Monteiro e Silvia de Alcântara (2008) expôs um panorama da azulejaria portuguesa e brasileira salientando o valor estético do azulejo, caracterizando-o como importante documento da cultura luso-brasileira.

No livro "Barroco memória viva: arte sacra colonial", Percival Tirapeli (2001) compilou vários artigos provenientes de palestras apresentadas nos cursos promovidos sobre o barroco. Apresentou considerações de importantes pesquisadores, mantendo como tema central a igreja, tomada como centro irradiador de cultura na época do Brasil colonial, devido a sua importância como construção histórica. Um desses textos é de autoria do professor Olympio Pinheiro, intitulado "Azulejo colonial luso-brasileiro: uma leitura plural", que procura mostrar ao leitor o sentido original do objeto azulejo, traçando os passos do processo semântico evolutivo e comparando com objetos e seus contextos dos dias atuais. Pinheiro revela como o 
azulejo foi percebido por diferentes épocas, uma vez que sofreu profundas alterações, não somente no plano técnico e tecnológico, mas, sobretudo, em sua função. Demonstra como o azulejo colonial dos séculos XVII e XVIII era um veículo de comunicação visual integrado à arquitetura religiosa, patrocinado pela aristocracia brasileira composta pela Igreja e seus superiores, Coroa e seus representantes, nobreza cortesã, senhores brancos administradores, comandantes militares, proprietários de terra, senhores de engenho, mineradores, grandes comerciantes, entre outros segmentos da sociedade.

A partir do estudo dessas obras e dos azulejos que ornamentam os Conventos Franciscanos de Olinda e do Recife torna-se possível compreender como este bem que integra o patrimônio cultural pernambucano se destaca por seus valores histórico e estético e como é notável a dificuldade na leitura total ou parcial de determinados painéis.

\section{Metodologia}

A pesquisa foi realizada em duas etapas que abarcaram processos de investigação na busca das informações relacionadas ao tema: 1. Revisão bibliográfica sobre o tema azulejaria no Brasil, pautada na análise de fontes como artigos, livros, dissertações e teses; 2 . Análise da ornamentação azulejar dos Conventos Franciscanos de Olinda e do Recife. Agregou-se a esta visitas aos conventos e registro fotográfico, ambos considerados como pesquisa de campo.

Após a revisão bibliográfica, discussão, análise e interpretação dos dados coletados, tratou-se de correlacionar o registro imagético com a avaliação das situações atuais dos painéis

\section{Convento de São Francisco de Olinda}

O Conjunto Franciscano de Olinda, localizado na Rua São Francisco, 280, na cidade de Olinda, Pernambuco, foi o primeiro estabelecimento dessa ordem no Brasil (Figura 1). Tombado pelo Instituto do Patrimônio Histórico e Artístico Nacional em 1938 (inscrição no 189 de 22 de Julho de 1938), é composto pela Igreja de Nossa Senhora das Neves e pelas Capelas de Santa Ana, do Capítulo, da Ordem Terceira de São Roque, claustro e sacristia.

Aspectos históricos e azulejaria do Convento Franciscano de Olinda

Entre 1500 e 1584 não havia uma presença regular da Ordem Franciscana no Brasil, apenas pequenos grupos de religiosos em missões evangelizadoras sem a introdução de conventos. Só em 1584 foi estabelecida a criação de uma Custódia ${ }^{1}$ Franciscana a pedido de Jorge de Albuquerque Coelho, então governador de Pernambuco, ao rei Felipe ${ }^{2}{ }^{2}$, da União Ibérica. Em

\footnotetext{
${ }^{1}$ Custódia ou comissariado denomina-se o conjunto dos conventos, antes de conquistar os foros de província, tendo a frente o Padre Comissário ou Custódio (Willeke, 1956, p.257).

${ }^{2}$ Em 1580, o rei de Portugal, D. Henrique, morreu sem deixar herdeiros. Surgiram disputas político-militares entre os pretendentes do trono português. O vencedor dessa disputa foi Felipe II, rei da Espanha. Com a ascensão de Felipe, teve início o período de domínio espanhol sobre Portugal denominado União Ibérica ou União Peninsular (Cotrim, 1999, p.187).
} 
13 de Março de 1584 foi deliberada a petição para a fundação da Custódia de Santo Antônio do Brasil, com sede na Vila Marim (hoje Olinda), tendo como primeiro Custódio o Frei Melchior de Santa Catarina (Mendes; Veríssimo; Bittar, 2007).

Em 10 de Janeiro de 1585 partiu do porto de Lisboa, com destino a Pernambuco, o navio que trouxe os frades responsáveis pela fundação da criada custódia franciscana do Brasil. No dia 12 de Abril de 1585 desembarcaram em Olinda o Frei Melchior de Santa Catarina, Frei Francisco de São Boaventura, nomeados por patente do geral da ordem, Frei Francisco dos Santos, Frei Afonso de Santa Maria, Frei Manuel da Cruz, Frei Antônio da Ilha, sacerdotes, Frei Antônio dos Mártires, corista, e Frei Francisco da Cruz, religioso leigo (Costa, 1951). Assim, iniciaram-se as atividades regulares da Ordem com a construção do primeiro convento, Nossa Senhora das Neves, em Olinda, e com o trabalho de evangelização através das missões, bem como com o atendimento aos colonos.

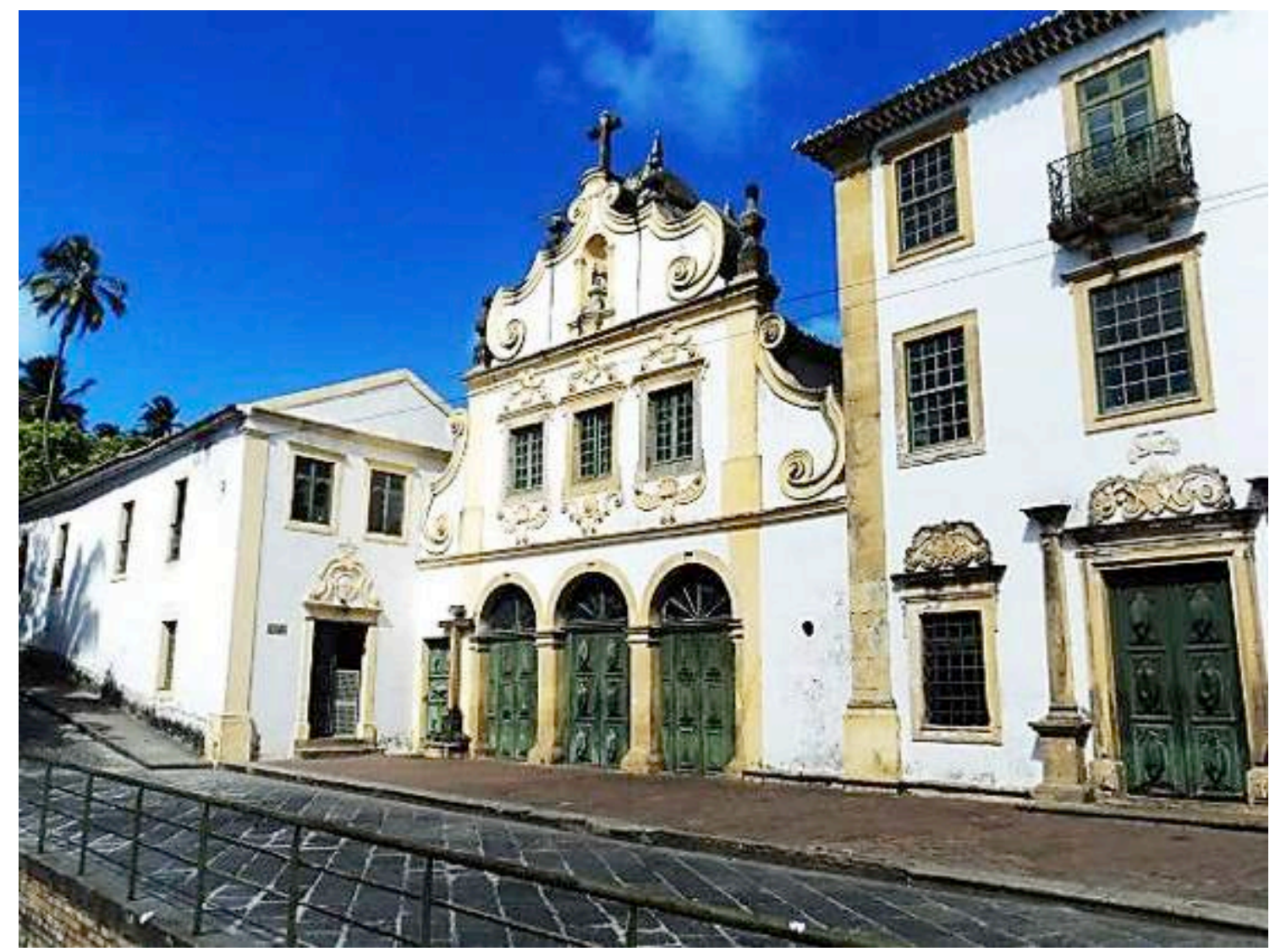

Figura 1: Convento Franciscano de Olinda, Pernambuco. Foto: Jaqueline Silva, 2014.

Conforme Costa (1951) os frades, primeiramente, habitaram uma casa próxima à igreja da Misericórdia, local onde ergueram um oratório ${ }^{3}$ no qual celebravam missas e outros atos religiosos. Permaneceram na habitação durante cinco meses, pois D. Maria da Rosa, terciária franciscana, viúva de Pedro Leitão, rico senhor de engenho, doou ao padre custódio dos

\footnotetext{
${ }^{3}$ Oratório ou hospício, chama-se a casa religiosa não formada, e cuja criação e supressão dependem unicamente dos superiores maiores da província (Willeke, 19565).
} 
franciscanos, frei Melchior de Santa Catarina e aos seus companheiros, as terras de sua propriedade nas quais ela construíra uma igreja e uma casa anexa destinada a um recolhimento de mulheres. Realizada a escritura de doação em 27 de Setembro de 1585, poucos dias depois, em 4 de Outubro do mesmo ano, os religiosos deixaram a casa e encaminharam-se para a igreja de Nossa Senhora das Neves.

Segundo Germain Bazin (1983 a), o arquiteto Frei Francisco dos Santos forneceu o risco do Convento Franciscano, em 1585, assim como o traço do Convento da Paraíba. Em 1586 os franciscanos deram início à realização de várias obras de acréscimo ao convento, finalizadas em Junho de 1590. No início do século XVII (entre 1627 e 1630) novas ampliações e adicionamentos foram efetuados.

Em 16 de Fevereiro de 1630 os holandeses invadiram Olinda ${ }^{4}$, mas os franciscanos só abandonaram o convento após o incêndio provocado pelo inimigo em 24 de Novembro de 1631 (Figura 2) (COSTA, 1951).
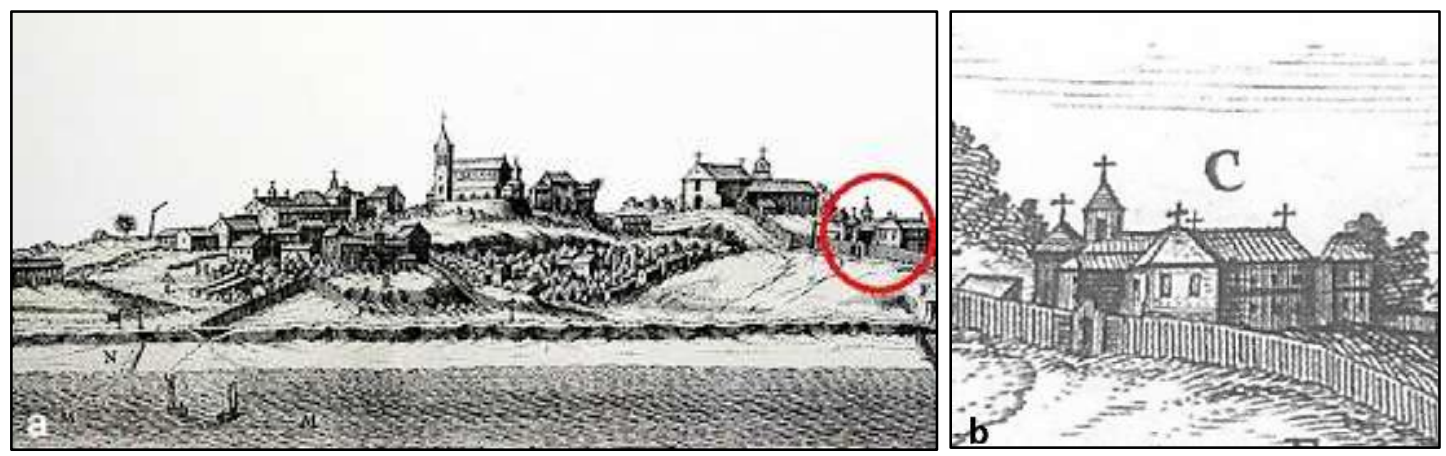

Figura 2: Vila de Olinda (Pernambuco) após o incêndio de 1631, desenho de Frans Post no livro de Gaspar Baerleus (a), em detalhe o Convento Franciscano de Olinda (b). Fonte: Zanchetl; Loretto; Moreira; Tinoco, 2011.

Com a rendição dos holandeses, em 1654, estes se retiram do Nordeste e, logo em seguida, os religiosos franciscanos ocuparam novamente o convento, cuidando dos reparos para recuperar o que restara (Costa, 1951).

$\mathrm{Na}$ Capela de Santa Ana se localizam dez painéis de azulejos, retratando a vida da santa (Figura 3). Os painéis, na coloração azul sobre fundo branco, crescem do rodapé de um azulejo (marmoreado manganês com ornatos simples da mesma cor), limitados por emolduramentos concheados e separados por colunas. De acordo com Simões "na fachada da portaria está gravada a data de 1754 e os azulejos serão coevos ou pouco posteriores" (Simões, 1965: 235).

\footnotetext{
${ }^{4}$ Reagindo ao bloqueio econômico espanhol, os holandeses fundaram a Companhia das Índias Ocidentais, em 1621. Decidiram, por meio dessa empresa, conquistar o Nordeste brasileiro e apoderar-se da produção de açúcar (Cotrim, 1999). 

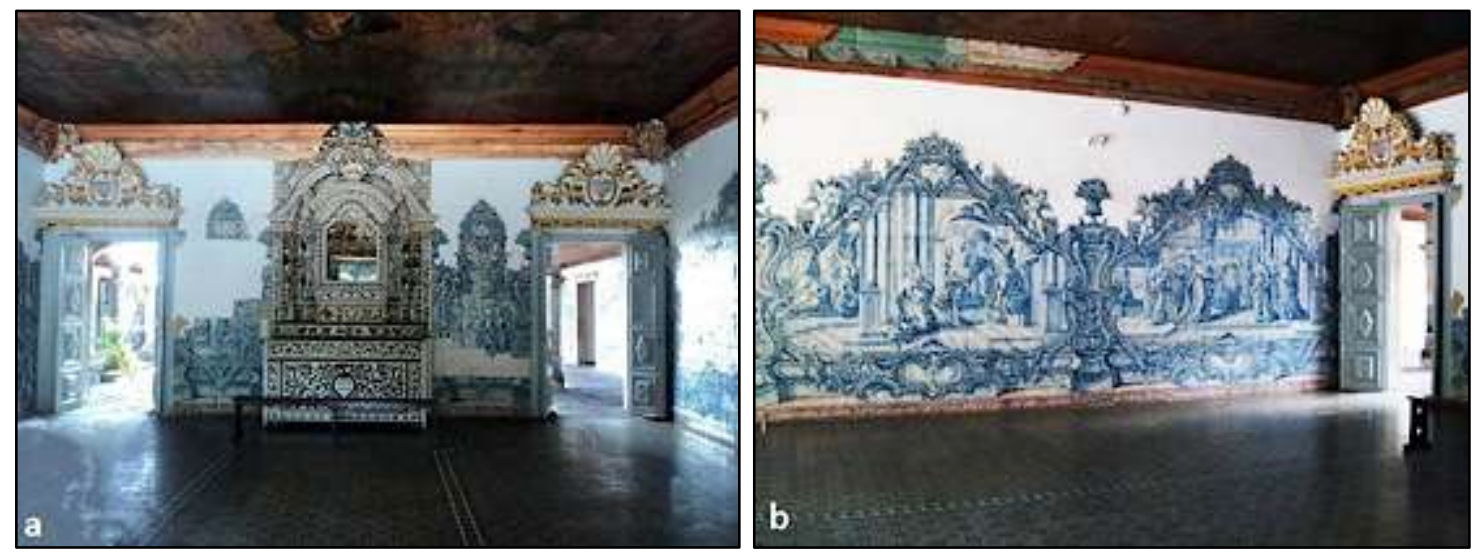

Figura 3: Capela de Santa Ana (a) e painéis representando a vida da santa (b), Convento Franciscano de Olinda, século XVIII. Foto: Jaqueline Silva, 2014.

Os painéis do claustro (Figura 4a), do início da primeira metade do século XVIII, são do mesmo tipo dos encontrados na Capela de Santa Ana, entretanto relatam a vida de São Francisco de Assis (Figura 4b). Somam-se dezesseis painéis monocromáticos portugueses em estilo barroco, de cor azul sobre fundo branco (Cavalcanti, 2006).
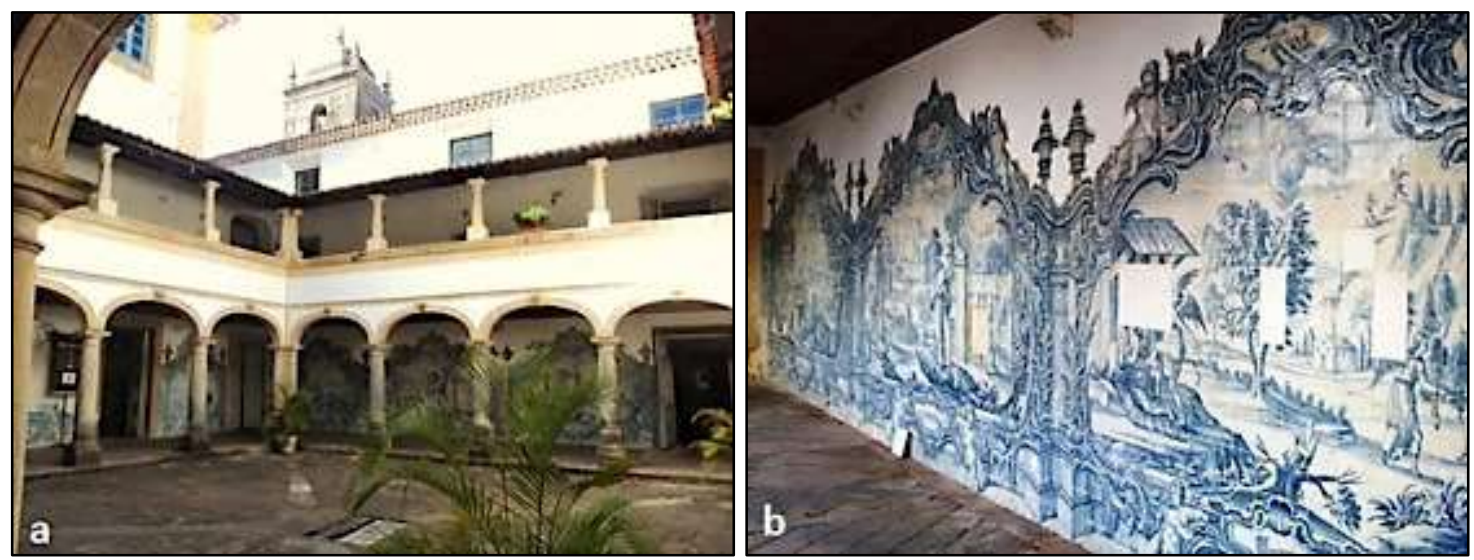

Figura 4: Claustro (a) e painéis ilustrando a vida de São Francisco de Assis (b), Convento Franciscano de Olinda, século XVIII. Foto: Jaqueline, 2014.

Na galeria sul do claustro está localizada a Capela do Capítulo (Figura 5 a), decorada com talha dourada e tapete de azulejos, os mais antigos do convento. Santos Simões (1965) constata que é difícil determinar a cronologia desses, admitindo a hipótese de serem anteriores a 1660 . 0 padrão dos azulejos é do tipo Massaroca, com centros de escamas e pontos amarelo e azul, e cercadura nos mesmos tons, mas em outro padrão (Figura $5 b$ ). 

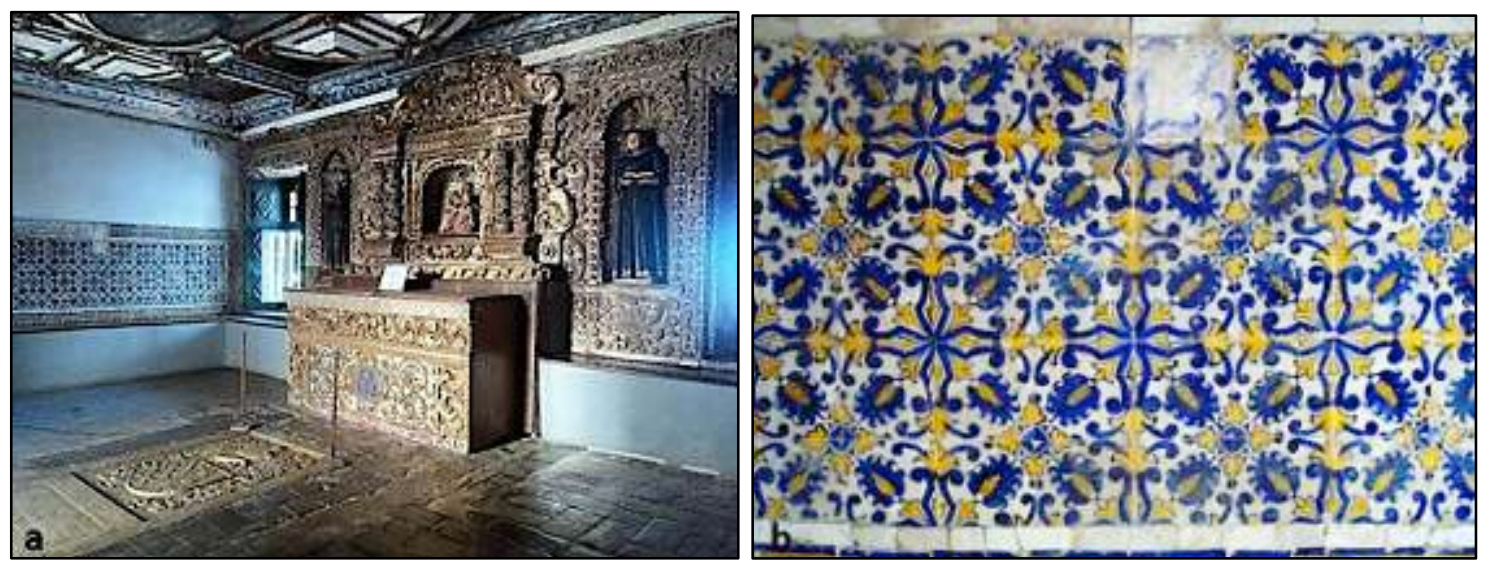

Figura 5: Capela do Capítulo (a) e detalhe do padrão Massaroca de "escamas" (b), Convento Franciscano de Olinda, século XVII. Foto: Jaqueline Silva, 2014.

No corredor que liga o claustro a sacristia (Figura 6a), mantêm-se silhares baixos, com onze peças de azulejos de altura que retratam cenas profanas compostas por fidalgos, pescadores, rebanhos, caçadores, casais, crianças, navios, entre outras (Figura 6b). A datação presumida é que sejam do primeiro quartel do século XVIII, próximo de 1720 (Cavalcanti, 2006).
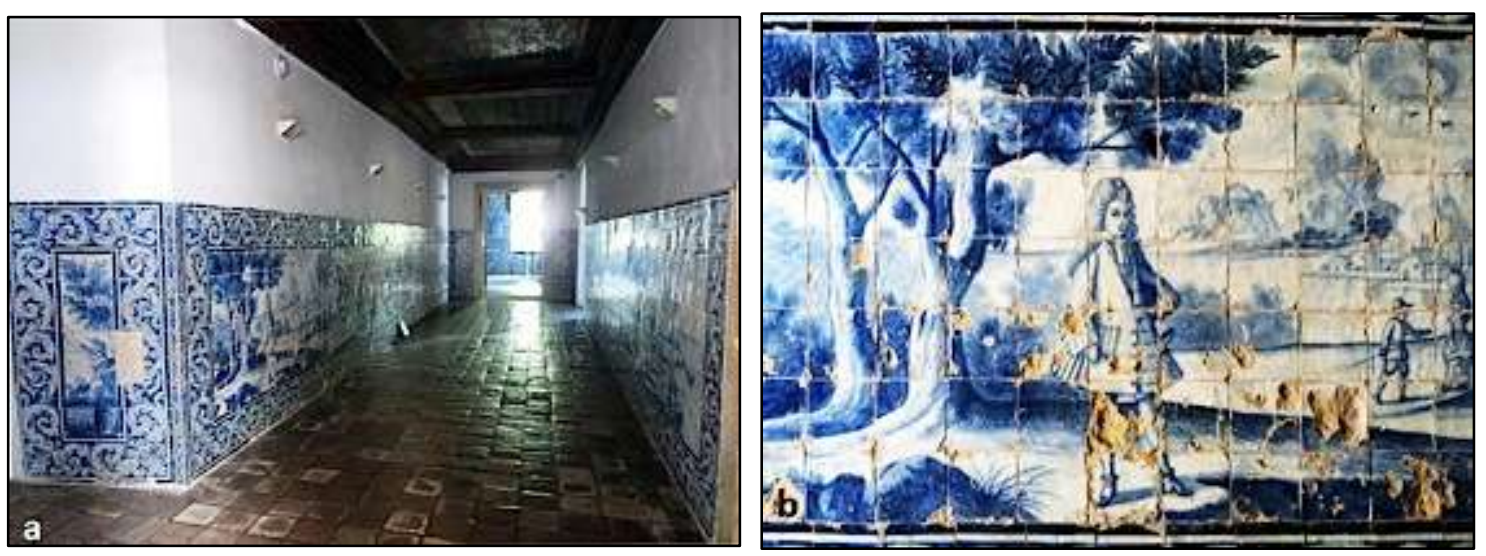

Figura 6: Corredor que une o claustro a sacristia (a) e pormenor do painel representando cena profana (fidalgo) (b), Convento Franciscano de Olinda, século XVIII. Foto: Jaqueline Silva, 2014.

A sacristia (Figura 7a) ostenta um teto com belos quadros de pinturas com temática franciscana, contornados por molduras e adornos, além daqueles com naturezas mortas compostas por frutas locais. A azulejaria ocupa todos os espaços parietais disponíveis, pois no mesmo local reside um $\operatorname{arcaz}^{5}$ de talha e um armário, (Figura 7b) (Cavalcanti, 2006).

"O esquema decorativo é o do azulejo azul, figurado, com alisar de 6 azulejos, acima do qual foram colocados, na parede do lado nascente, dois grandes painéis de 17 de altura por 16,5 de largura, incluindo a moldura de 2 azulejos. Os painéis apresentam São Francisco recebendo os estigmas e 0 Menino Jesus aparecendo a Santo Antônio. Aliás, pelo tipo de pintura, coloração, composição - ainda muito clássica na moldura - e presença de

\footnotetext{
${ }^{5}$ Arca grande, provida de gavetões, onde se guardam os paramentos sacerdotais na sacristia da igreja (Calado e Silva, 2005: 35 ).
} 
óvulos, esta obra parece poder ser de cerca de 1717-20" (Simões, 1965: 237, grifo do autor).
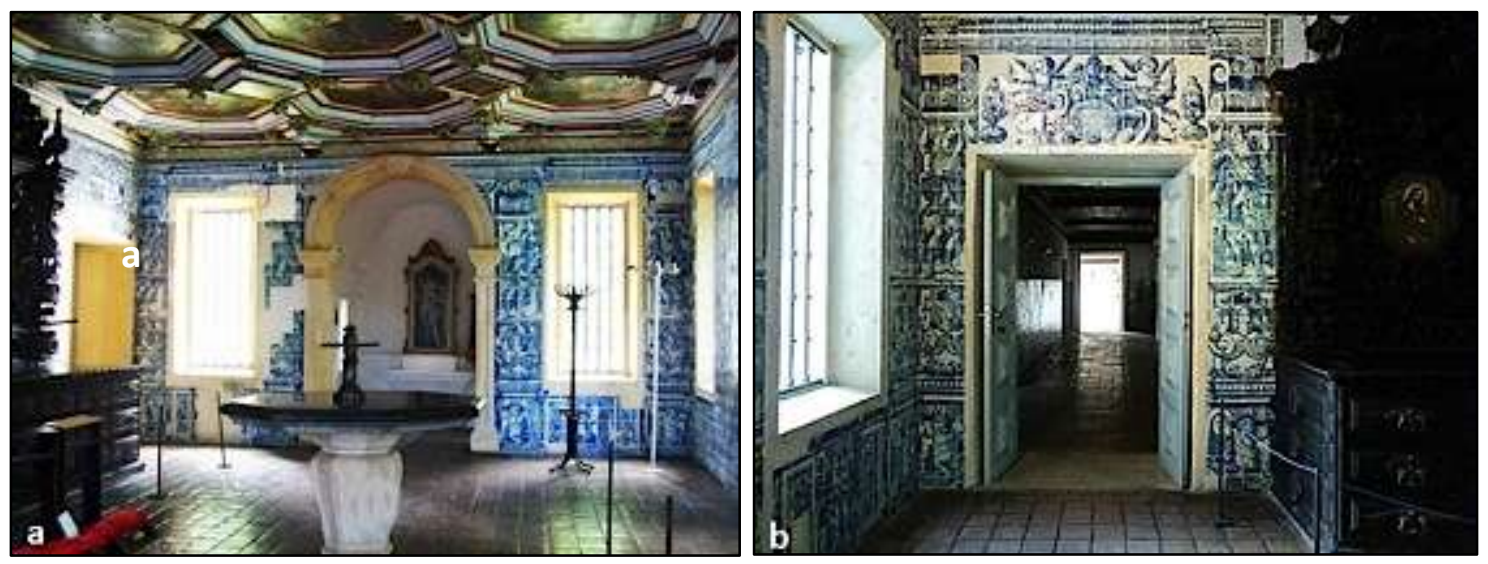

Figura 7: Sacristia do Convento Franciscano de Olinda (a e b), século XVIII. Foto: Jaqueline Silva, 2014.

No corpo da nave da igreja do convento a azulejaria ocupa as extensas laterais, abordando a vida de Nossa Senhora e de Jesus, colocados por ordem narrativa, retirada dos evangelhos de São Lucas e de São Mateus (Figura 8a) (Simões, 1965). São doze painéis que se encontram sobre um rodapé marmoreado de manganês sem ornamentação, contrastando com o azul das pinturas. Apresentam inscrições em latim inseridas em florões centrais, no alto da composição, margeados por anjos e encimados por rostos de figura angelical. São intercalados pelas clássicas colunas adornadas por anjinhos, na base, mas sem os habituais vasos ou urnas como arremate superior (Figura 8b) (Cavalcanti, 2006). De acordo com Simões (1965), os enquadramentos são barrocos e apenas apontam elementos concheados, o que permite supor sua datação por volta de 1745 .
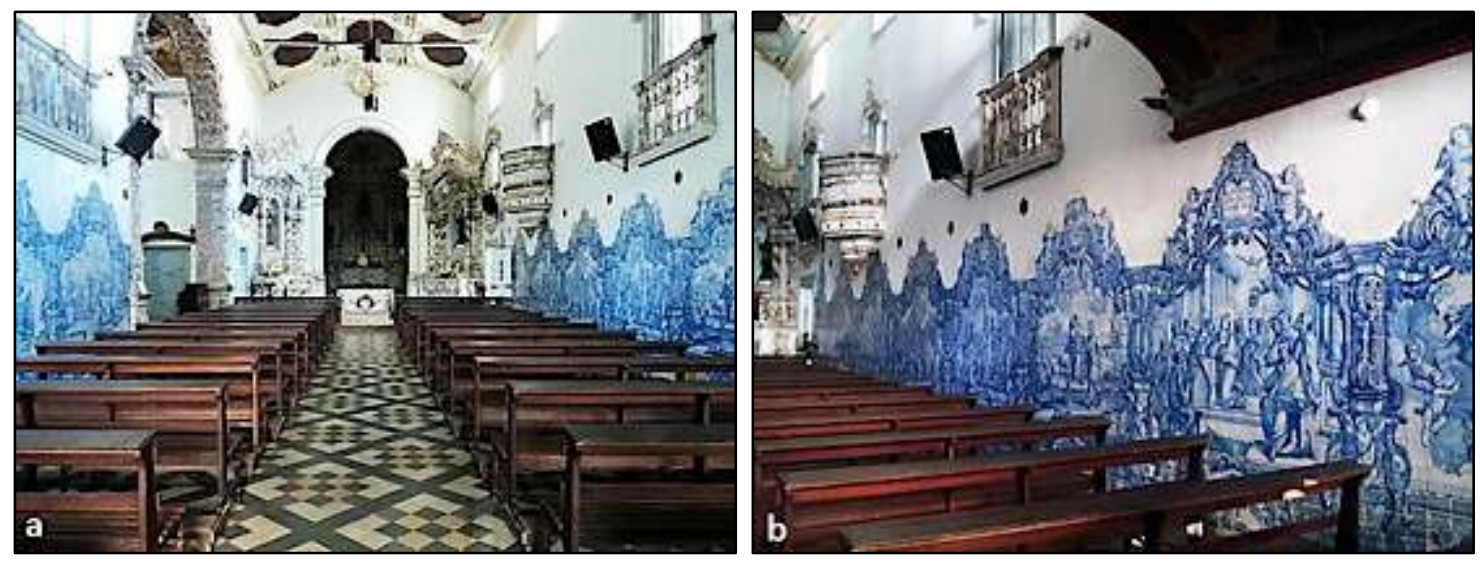

Figura 8: Igreja de Nossa Senhora das Neves (a) e painéis ilustrando cenas da vida da santa (b), Convento Franciscano de Olinda, século XVIII. Foto: Jaqueline Silva, 2014.

Simões (1965), baseando-se em características técnicas e estilísticas, resume a ordenação cronológica do complexo azulejar do Convento de Olinda da seguinte forma:

10 - Cerca de 1650-70, azulejos da Capela do Capítulo e da escada; 
2o - Cerca de 1720-20, painéis da parte superior da sacristia;

3o - Cerca de 1720-25, painéis do corredor;

40- Cerca de 1735-45, azulejos do claustro, da nave da igreja e parte inferior das paredes da sacristia;

5o - Cerca de 1754, painéis da Capela de Santa Ana.

\section{Convento Franciscano de Santo Antônio do Recife}

Localizado na Rua do Imperador Dom Pedro II, s/no, na cidade do Recife, Pernambuco, encontra-se o conjunto franciscano do Recife (Figura 9). Formado pelas Capelas de Nossa Senhora da Saúde, do Rosário, da Ordem Terceira de São Francisco, Igreja de Santo Antônio, claustro e sacristia, foi tombado pelo Instituto do Patrimônio Histórico e Artístico Nacional em 1938 (inscrição no 186 de 20 de Julho de 1938).

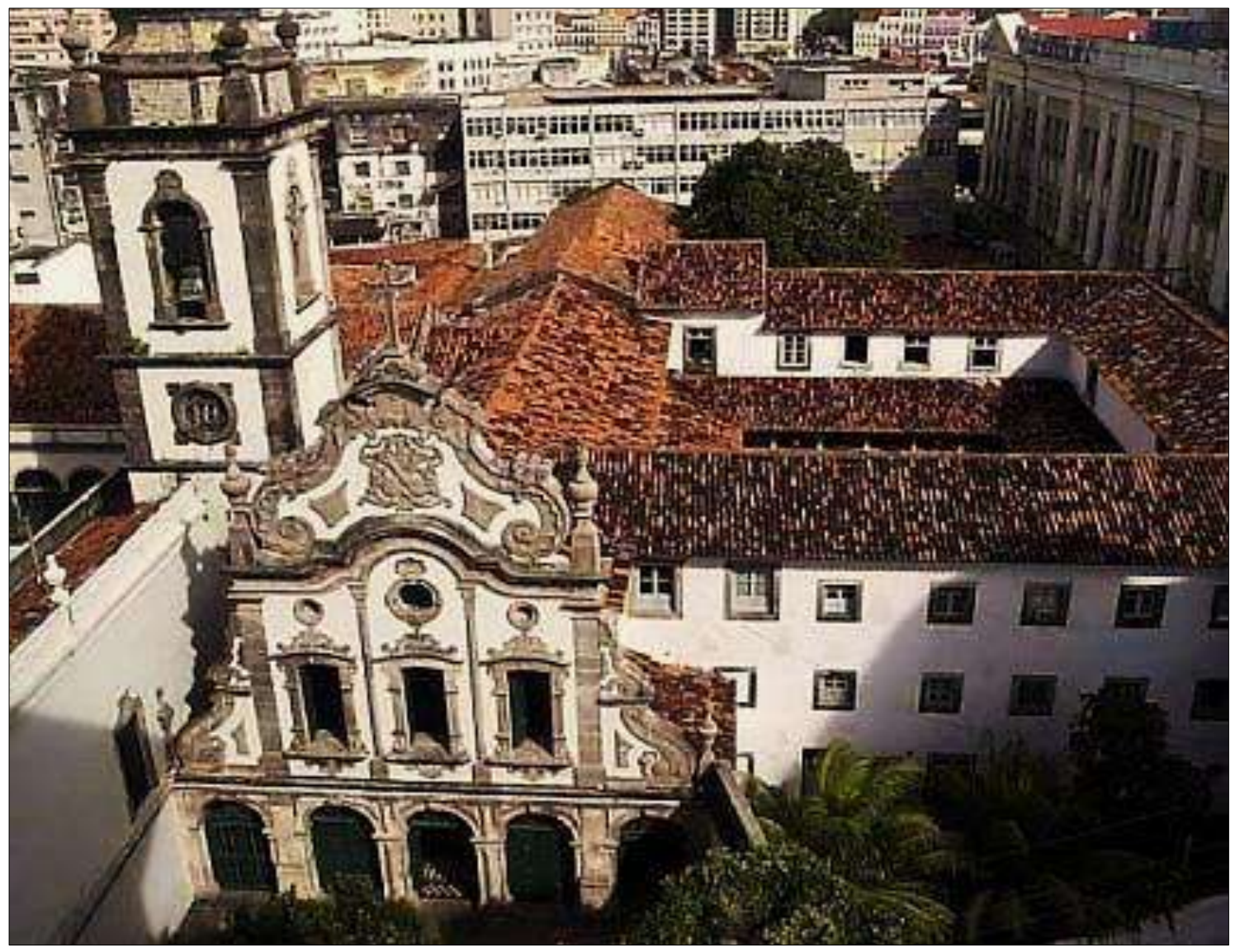

Figura 9: Convento Franciscano de Santo Antônio, Recife, Pernambuco. Fonte: https://www.google.com.br/search?q=Convento+santo+antonio+recife (2014) 
Aspectos históricos e azulejaria do Convento Franciscano do Recife

O local onde foi edificado o conjunto franciscano do Recife era de posse de Jerônimo de Albuquerque, português que chegou em 1535, acompanhado por seu cunhado, o primeiro donatário da capitania de Pernambuco, Duarte Coelho Pereira. Após a morte de Jerônimo, um de seus filhos, que herdou a área, vendeu-a a um dos mais ricos comerciantes daquela época, chamado Marcos André, passando então o nome do local a ser denominado de llha de Marcos André (Cavalcanti, 2006).

Em 28 de Outubro de 1606, no Convento Franciscano de Olinda, formou-se uma junta ${ }^{6}$ convocada pelo Frei Leonardo de Jesus para aceitação da construção do Convento em Recife.

Em 14 de Dezembro de 1606, Marcos André, colono e proprietário da Ilha dos Navios, fez a doação do terreno para a construção do Convento, "constante de cinquenta e seis braças de testada, ao longo da praia de Norte a Sul e de Leste a Oeste, na dita llha dos Navios" (Costa, 1952a: 239). Inicialmente foi construída uma casa para habitação dos padres, junto a um oratório para os exercícios dos religiosos no próprio local onde se fundou o convento. Era comum os frades franciscanos edificarem primeiro uma residência provisória ou "recolhimento" com oratório pois, às vezes, o primitivo local escolhido não se apresentava próprio para fixar o convento. De acordo com o Frei Jaboatão o convento foi traçado pelo mestre pedreiro Manuel Gonçalves Olinda (Mueller, 1956).

Ressalta-se que no frontispício da Igreja encontra-se a inscrição "Anno 1606", entretanto esta data corresponde ao ano de doação das terras por parte de Marcos André, o que não indica o lançamento da primeira pedra, nem mesmo refere-se ao lugar exato onde se levantou o primitivo recolhimento (MUELLER, 1956).

Mueller (1956) destaca que com a resolução de construir o convento em 1606, os religiosos poderiam ter gasto dois anos, para angariar materiais e esmolas, até iniciar as obras, ainda que provisórias, do oratório e recolhimento que existiam em 1609. As obras da construção terminaram na administração do Frei Bernardino de São Tiago, por volta de 1612 e 1613. (Costa, 1952a).

Com a invasão holandesa ao estado de Pernambuco, em 1630, o guardião Frei Luís da Anunciação juntamente aos outros frades do Convento de Recife e, os religiosos do Convento de Olinda abandonaram-no, alguns se recolheram em conventos de outras ordens, os outros seguiram com o Frei para o Arraial do Bom Jesus e ficaram até 8 de Junho de 1635, dia em que o Arraial foi tomado pelos holandeses (Costa, 1952a).

Quando os holandeses ocuparam o convento foram levantados quartéis e uma praça de defesa denominada Forte ${ }^{7}$ Ernesto que não chegou a ser concluída (Figura 10).

\footnotetext{
${ }^{6}$ Junta é uma reunião dos superiores de uma Custódia (Willeke, 1956: 258).

${ }^{7}$ Forte é uma construção levantada em local estratégico destinada a abrigar peças de artilharia e soldados, a fim de defender uma praça, uma cidade, uma região etc (Calado e Silva, 2005: 169). 


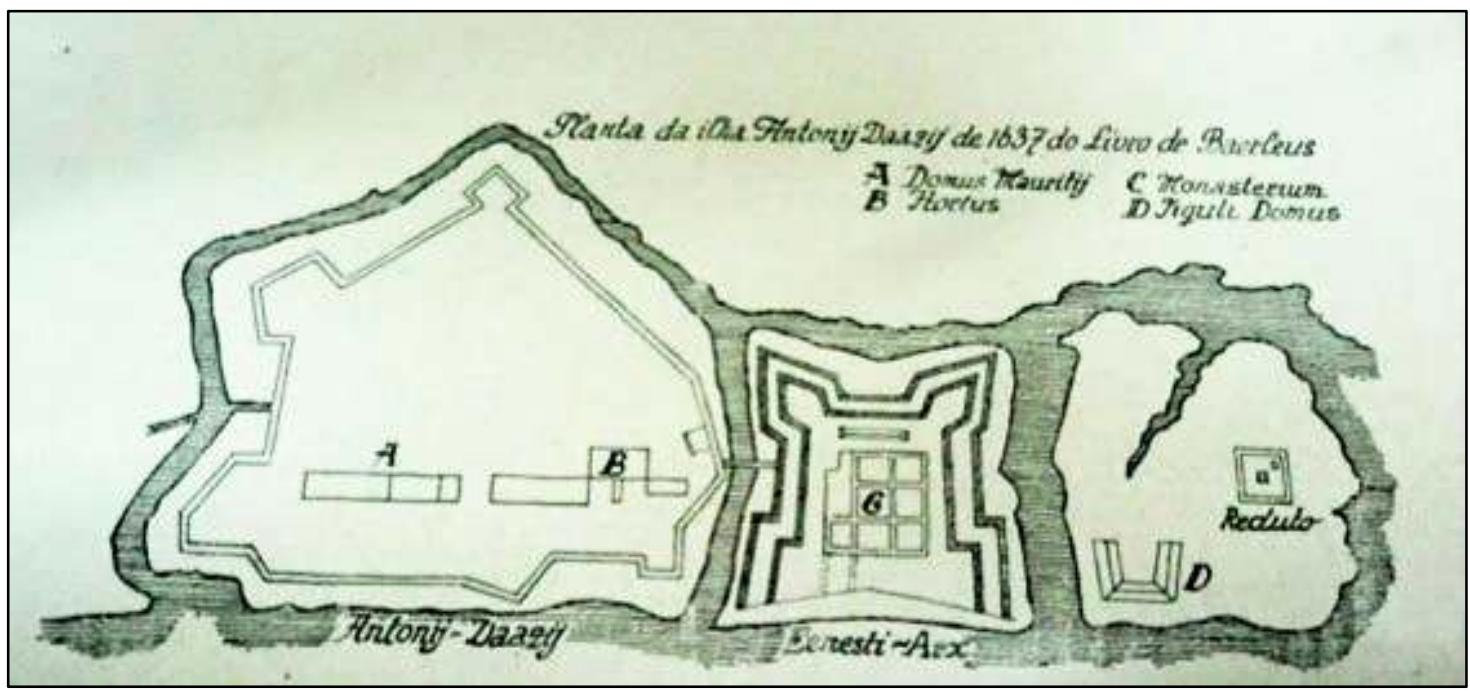

Figura 10: Planta da Ilha de Antônio Vaz (Bairro de Santo Antônio do Recife), ao centro vê-se o Forte Ernesto. Fonte: Mueller, 1956.

Após a retirada dos holandeses, em 1654, com a destruição do forte e retomada do convento pelos franciscanos, estes se ocuparam com a reparação dos danos que foram "causados pelo inimigo e pelo tempo" (Costa, 1952a: 240).

O aspecto atual do frontispício, com os cinco arcos de pedra, não é o mesmo da época holandesa (Mueller 1956). A partir de 1710 os conventos franciscanos, reconstruídos e modificados, exibiam os aspectos do estilo barroco. Em uma placa em frente ao convento informa-se que entre os anos de 1702-1770 foi reformado no estilo barroco.

A partir da segunda metade do século XVII, de 1660 em diante, começam a chegar as primeiras peças do acervo azulejar que ornamentam as superfícies parietais do conjunto franciscano (Cavalcanti, 2006).

$\mathrm{Na}$ entrada do convento há um vestíbulo ${ }^{8}$ com azulejaria ornamental e, logo em seguida, na sala onde já existiu uma capela - de Nossa Senhora da Saúde - e virou portaria/secretaria, encontram-se cinco painéis de azulejos portugueses do século XVIII, de pintura azul sobre fundo branco e enquadramento concheado, com legendas em latim (Figura 11), obedecendo à seguinte ordem:

À esquerda (na parede sul) o maior deles, Sinco Martires em Marrocos; em frente (parede oeste), um pouco encoberto por uma divisória de madeira afixada no piso e acima do painel, está o Sete Martires em Ceupta; na parede norte existem dois painéis menores separados por um intervalo onde certamente ficava o altar Martires no Japan e Silencio; finalmente, no verso do frontispício (parede leste) está o quinto, Martires em Genebra (Cavalcanti, 2006: 78, grifo nosso).

\footnotetext{
${ }^{8}$ Vestíbulo é o espaço menor ou maior entre a via pública e a entrada de um edifício (Calado e Silva, 2005). 


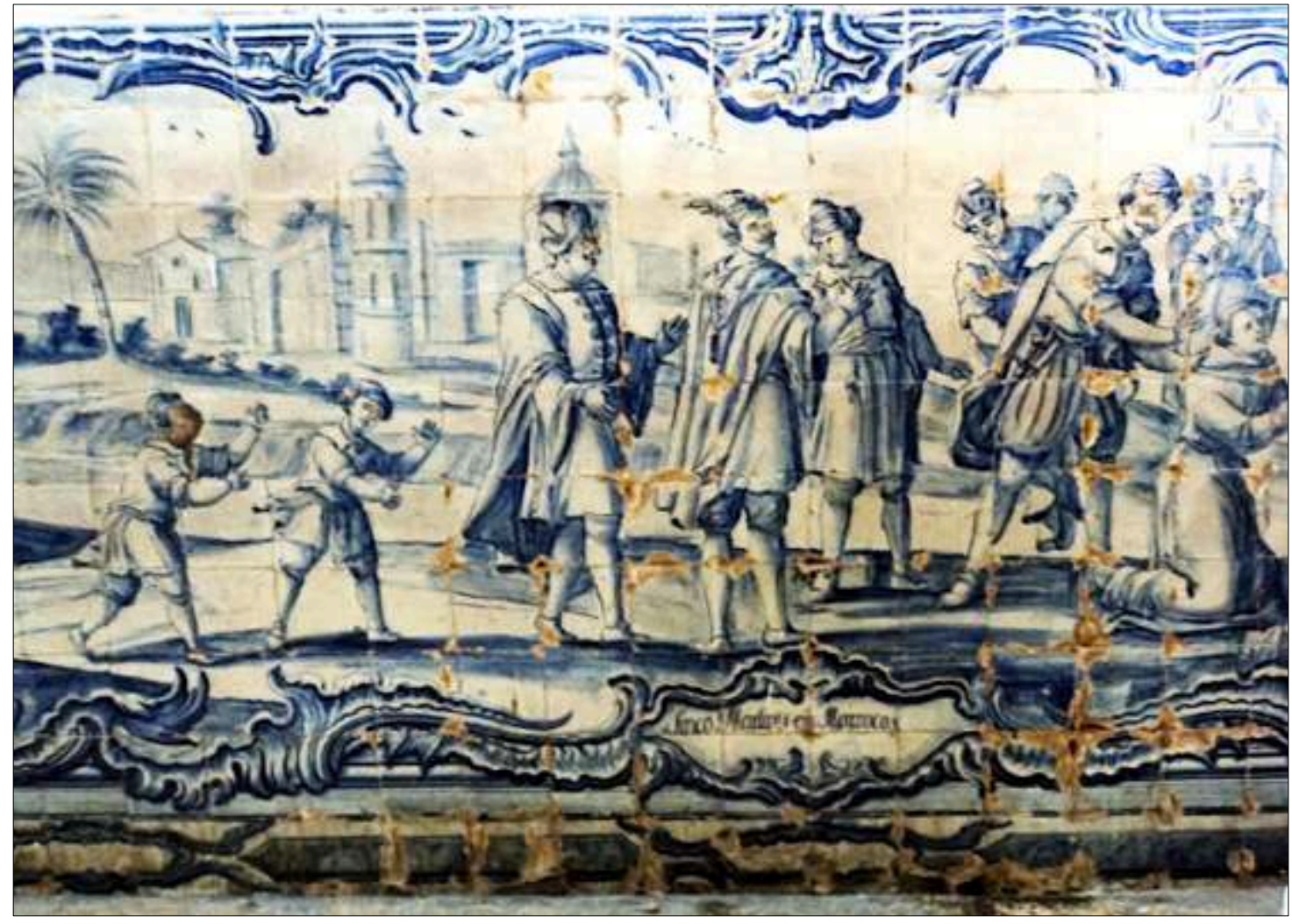

Figura 11: Detalhe do painel, localizado na portaria, que representa os Cinco Mártires em Marrocos, Convento Franciscano do Recife, século XVIII. Foto: Jaqueline Silva, 2014.

O claustro é igualmente harmonioso, com pavimento térreo composto por arcos que descansam sobre colunas toscanas (Figura 12a) e paredes com aplicação de painéis de azulejos portugueses da primeira metade do século XVIII (Figura 12b).
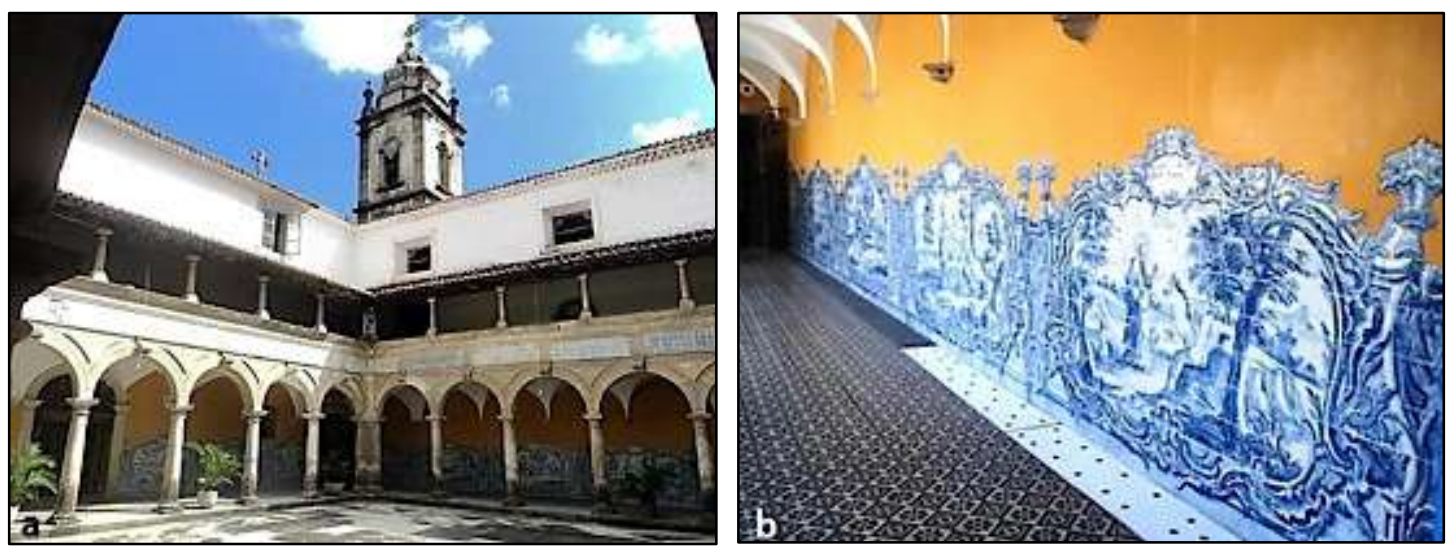

Figura 12: Claustro (a) e painéis ilustrando cenas bíblicas (b), Convento Franciscano do Recife, século XVIII. Foto: Jaqueline Silva, 2014.

Convém ressaltar que se agrupam aos azulejos do claustro os do corredor de acesso à sacristia (Figura 13a), constituindo um conjunto de vinte e sete painéis. De acordo Frei Bonifácio Müller (1956) o mestre copista utilizou como base para a criação dos temas e das figurações dos painéis as imagens existentes na Histoire Sacreé de la Providence, da Bíblia de Demarne, 
conhecida como a Bíblia de Rafael. São cenas que retratam a criação do mundo e do homem, a queda no paraíso, a construção da Arca de Noé, o Dilúvio, cenas da vida de Abraão até a construção da Torre de Babel. Cada painel possui emolduramento concheado, de coloração azul sobre fundo branco. Ao centro da parte superior dos painéis as inscrições latinas referenciam as cenas pintadas (Figura 13b).
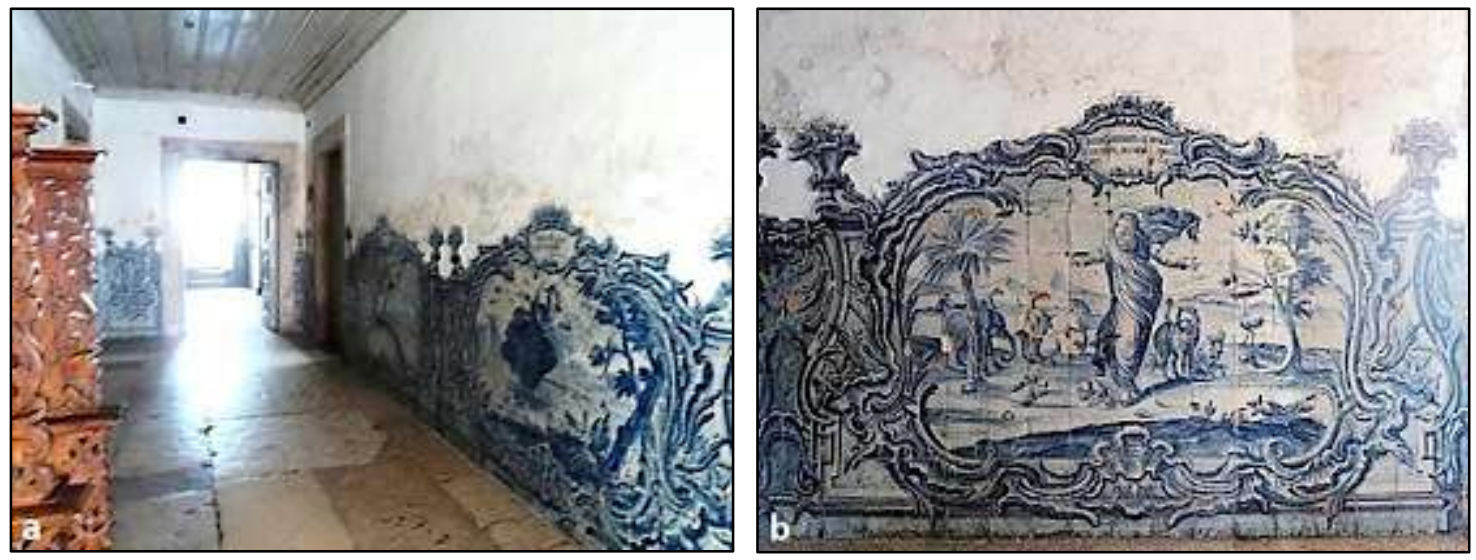

Figura 13: Corredor que une o claustro a sacristia (a) e painel representando Deus fazendo os animais em espécies variadas (b), Convento Franciscano do Recife, século XVIII. Foto: Jaqueline Silva, 2014.

Na Capela de Nossa Senhora do Rosário o revestimento azulejar é composto por quatro grandes painéis que cobrem as quatro paredes até quase o forro (Figura 14). Os painéis são concheados e emoldurados por colunas encimadas por vasos nas extremidades e possuem inscrições em português na parte superior (Cavalcanti, 2006).

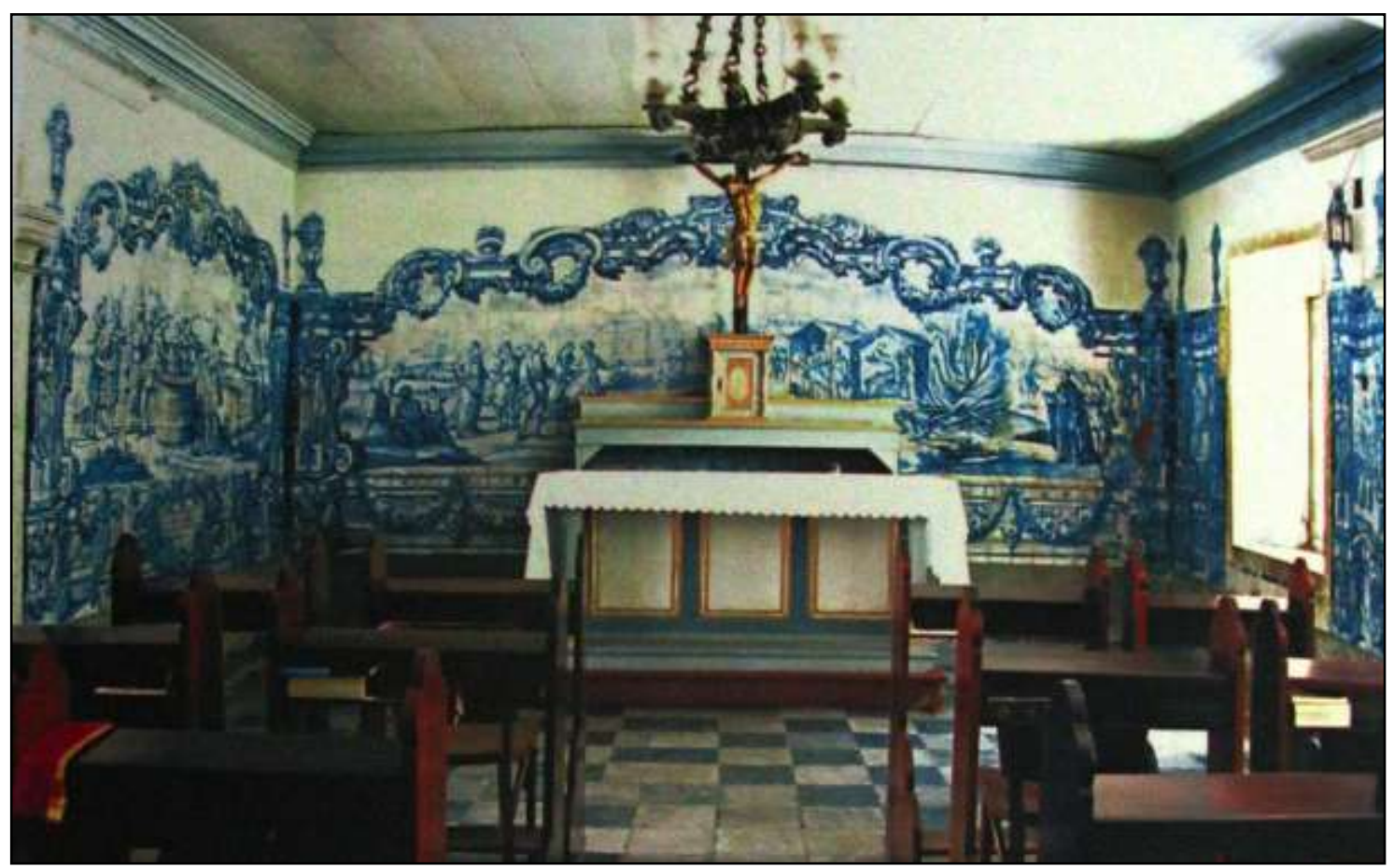

Figura 14: Capela de Nossa Senhora do Rosário, Convento Franciscano do Recife, século XVIII. Fonte: Cavalcanti, 2006. 
Na sacristia (Figura 15a), localizada atrás da capela-mor, as superfícies parietais livres do mobiliário - existe um arcaz na parede leste e dois armários embutidos na parede oeste, todos em jacarandá - encontram-se revestidas de azulejos ornamentais que são contemporâneos aos do claustro e do corredor, datados do século XVIII, de coloração azul de cobalto sobre fundo branco de estanho. No lavabo há pequenos painéis nas laterais, retratando passagens da vida de Santo Antônio (Figura 15b) (Cavalcanti, 2006).
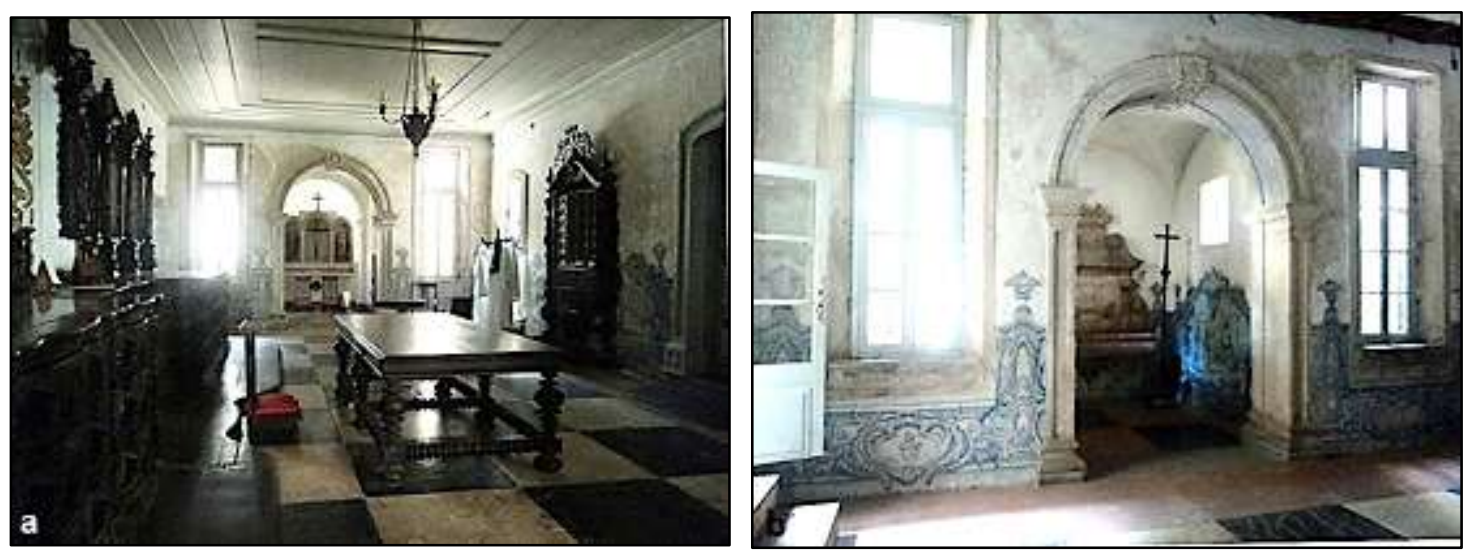

Figura 15: Sacristia (a) e lavabo com painéis representando cenas antonianas (b), Convento Franciscano do Recife, século XVIII. Foto: Jaqueline Silva, 2014.

Na igreja do convento (Figura 16a), em toda a nave, estende-se um silhar azulejado composto por onze painéis concheados e emoldurados por pilastras encimadas por vasos nas extremidades, em monocromia azul e branco, com representações de figuras angelicais típicas do barroco e cenas que retratam a vida e os milagres de Santo Antônio de Lisboa (Figura 16b). Em quase todos os painéis, no centro da parte inferior, lê-se uma inscrição latina (Cavalcanti, 2006).
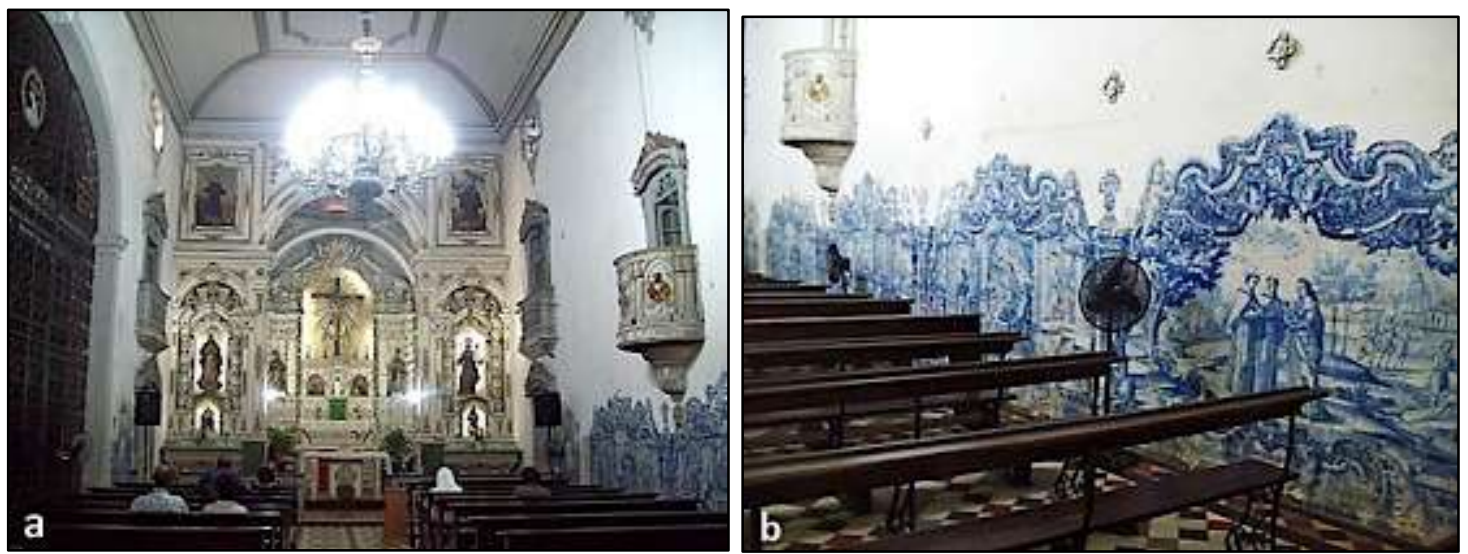

Figura 16: Igreja (a) e painéis representando a vida e os milagres de Santo Antônio (b), Convento Franciscano do Recife, século XVIII. Foto: Jaqueline Silva, 2014.

A Capela da Ordem Terceira conserva em suas paredes crucifixos de azulejo que marcam Os Passos da Paixão, também chamada de Capela Dourada. É toda entalhada em madeira (cedro), em estilo barroco, recoberta com gesso e lâminas de ouro (Figura 17). Os azulejos estão 
dispostos em silhares baixos, divididos em três painéis de cada lado, representando cenas de caça (Figura 18).

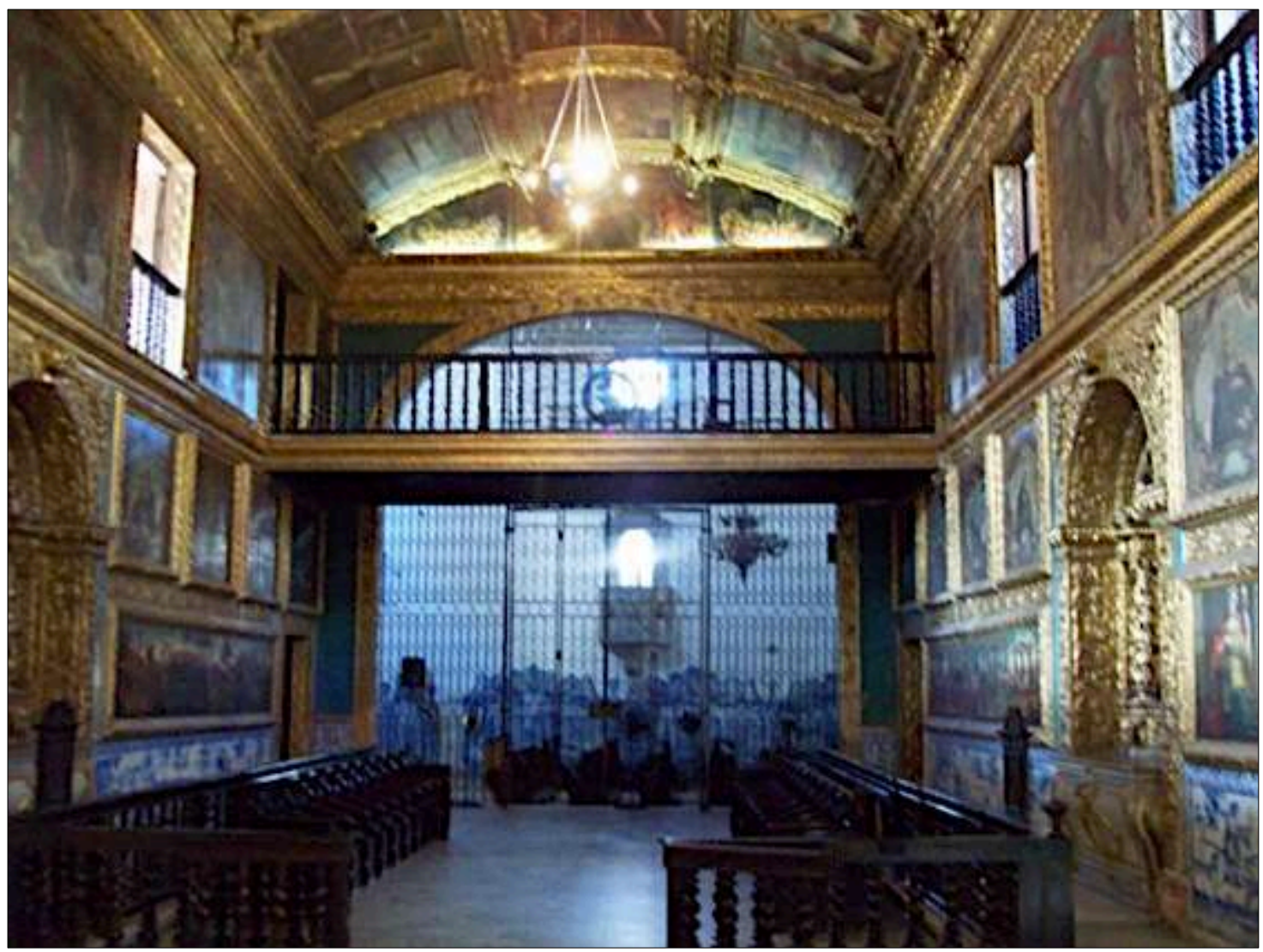

Figura 17: Capela da Ordem Terceira (Capela Dourada), Convento Franciscano do Recife, século XVIII. Foto: Jaqueline Silva, 2014.
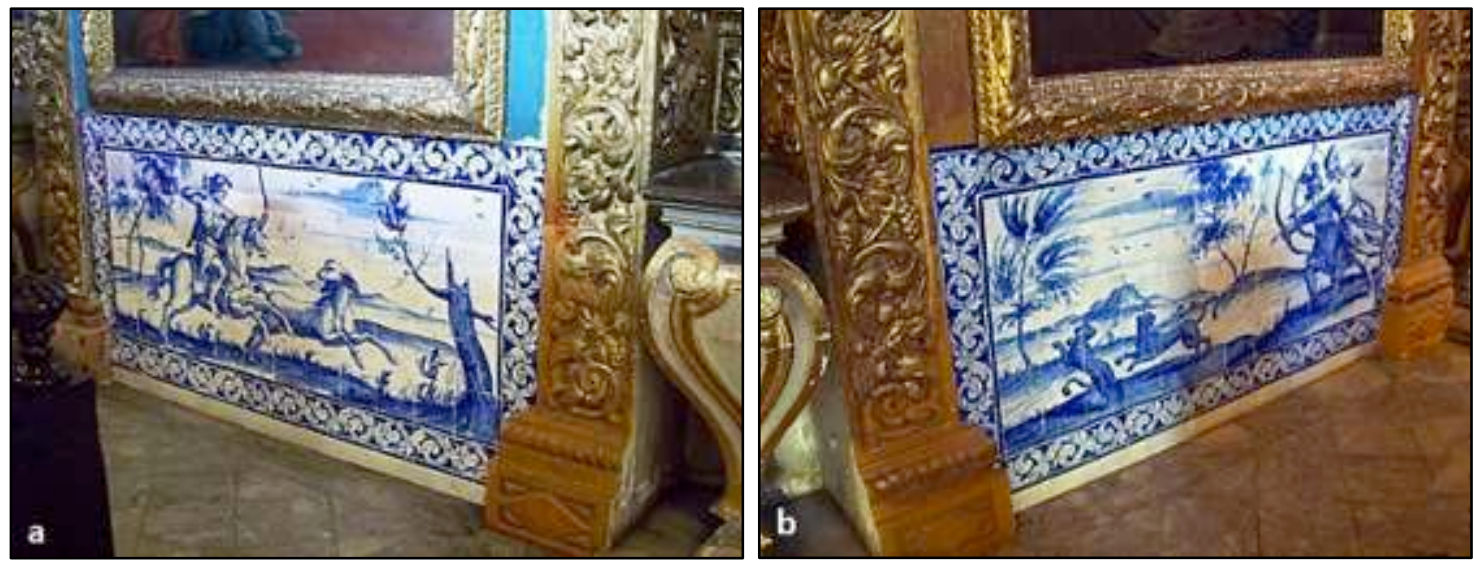

Figura 18: Painéis figurativos historiados (cenas de caça) (a e b), Capela da Ordem Terceira do Convento Franciscano do Recife, século XVIII. Fonte: Jaqueline Silva, 2014.

Cavalcanti (2006) salienta que se sabe com certeza a data de produção dos painéis, pois entre documentos encontrados pelo professor José Antônio Gonsalves de Melo, nos arquivos da própria Ordem Terceira, há uma carta endereçada a Lisboa para Antônio Teixeira de Almeida, 
datada de 10 de Outubro de 1702, encomendando os azulejos e a resposta, em 10 de Setembro de 1703, anunciando a vinda dos mesmos. Outro fato importante na confirmação da cronologia desses painéis é que um deles foi assinado pelo autor, Antônio Pereira, um grande representante do Ciclo dos Mestres na produção da azulejaria do século XVIII (Figura 19).

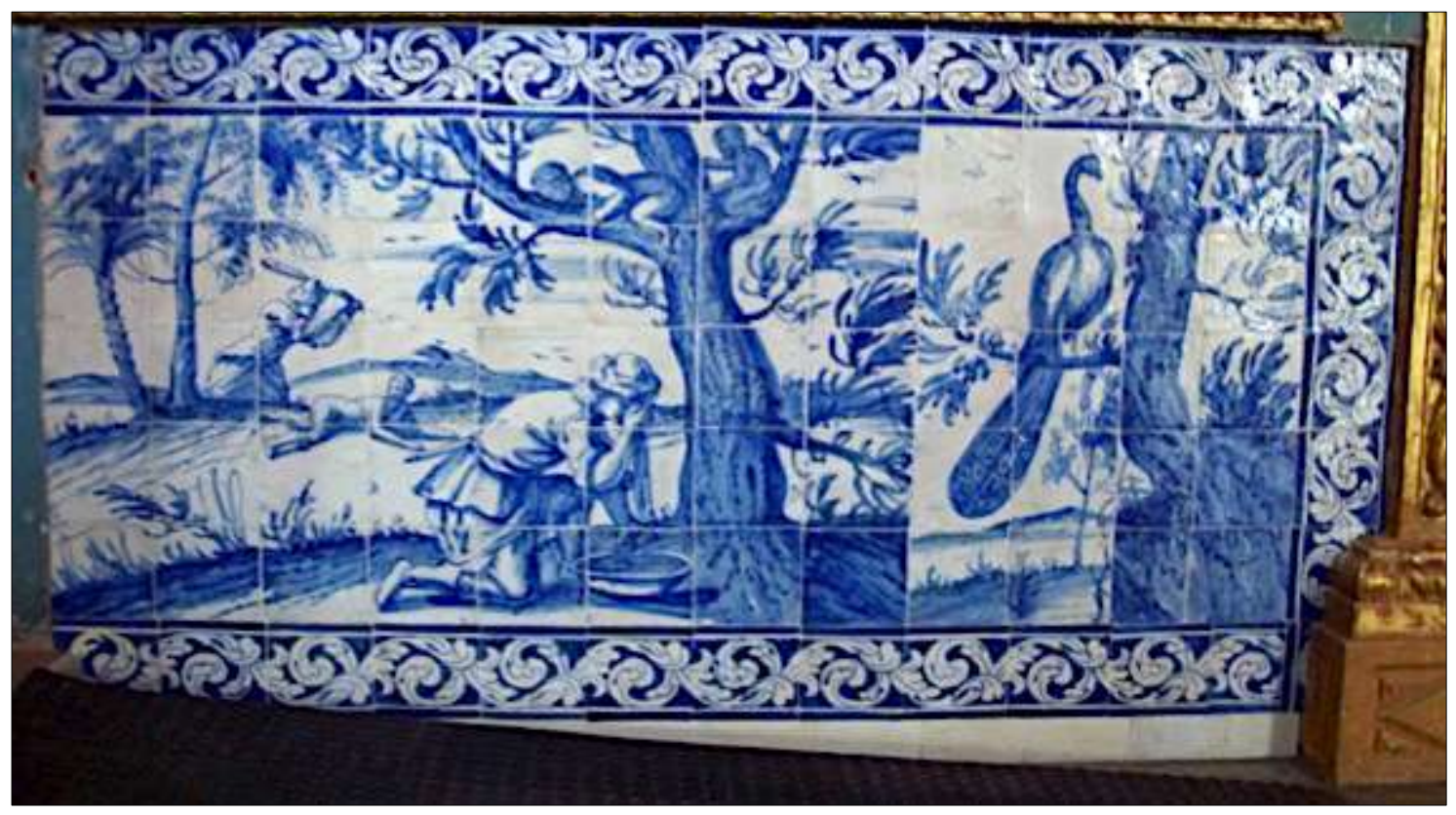

Figura 19: Painel retratando cena de caça, assinado por Antônio Pereira, altar-mor da Capela da Ordem Terceira do Convento Franciscano do Recife, século XVIII. Foto: Jaqueline Silva, 2014.

Simões (1965), através da história do edifício e da análise crítica do repertório azulejar do Convento de Santo Antônio do Recife, considera quatro períodos para a instalação dos azulejos:

1 o - Antes de 1660 serão os restos de um painel (ou frontal de altar) policromo e a guarnição floral na escada e no patamar;

2ㅇ - Durante a ocupação holandesa, os azulejos da galeria do claustro foram importados nessa época, talvez destinados ao Palácio de Maurício de Nassau.

3o - Ainda no século XVII - 1660-90 - os azulejos de padrões policromos da capela-mor e azuis da escada e galeria superior do claustro, sendo provável que nesse período tenham sido colocados os azulejos holandeses;

40 - Finalmente de 1755-60 os painéis da igreja, do piso inferior do claustro, do corredor do átrio, da portaria e da sacristia. 
Situações que Tornam Impossível a Leitura Total ou Parcial dos Painéis Figurativos Historiados de Azulejos dos Conventos Franciscanos de Olinda e do Recife

Provavelmente durante todo o processo de transporte até a chegada dos azulejos na colônia, algum acidente ocorria, quebrando-se uma ou várias peças. Isto, de fato, não ocasionava grandes prejuízos durante o século XVII, pois os painéis eram em tapetes, constituídos pela repetição de padrões. No entanto, no século XVIII os acidentes de transporte acarretavam enormes danos ao conjunto, por se tratar de painéis historiados formados por peças únicas que, reunidos formavam as cenas. Em alguns desses painéis ocorreu a colocação inadequada de peças de azulejos que diferem das cenas originais, causada pela ausência das pedras originais em sua composição cenográfica (Figuras 20 e 21).
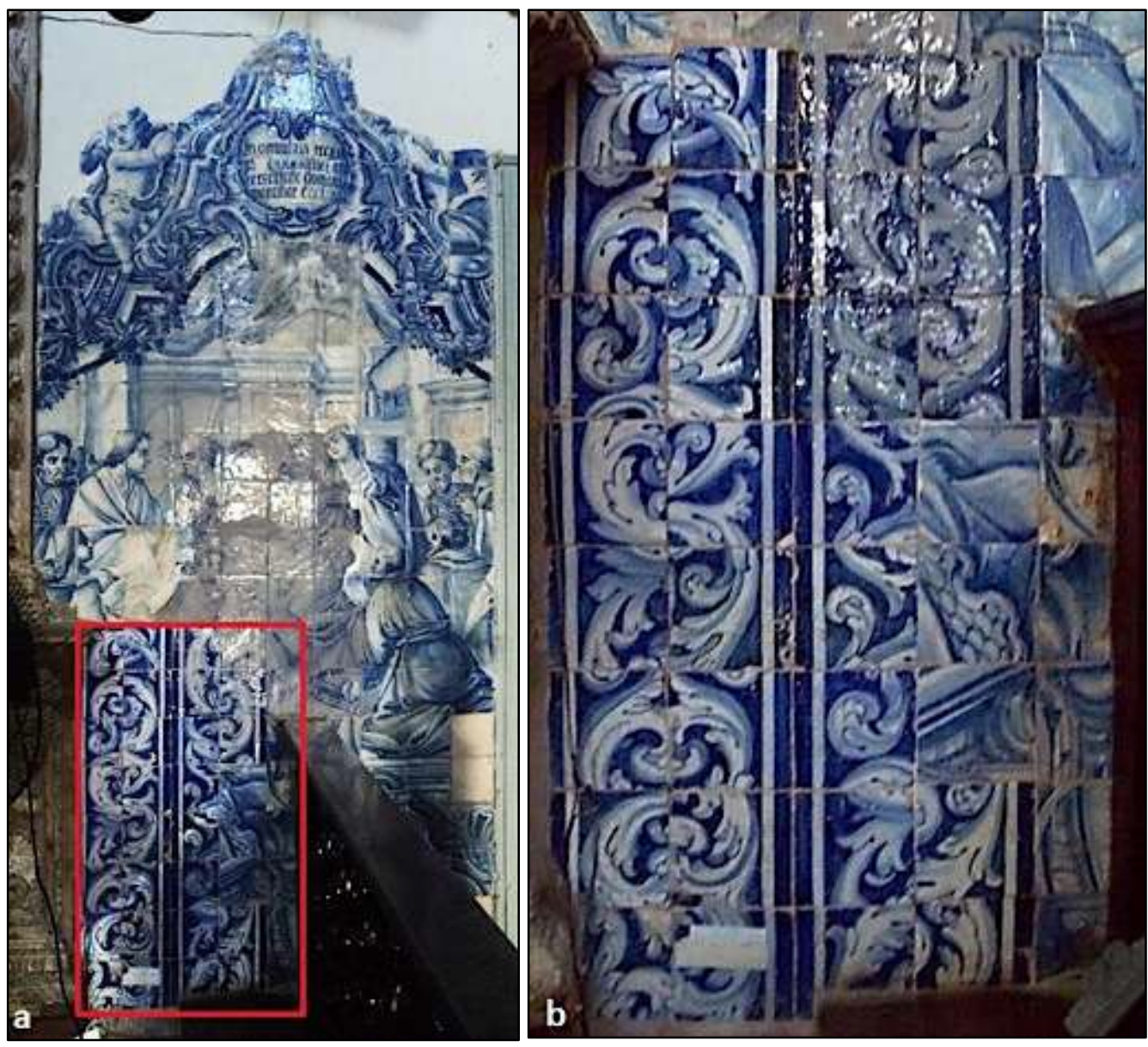

Figura 20: Painel representando a morte de Nossa Senhora (a) e detalhe das peças diferentes das primitivas (b), Igreja de Nossa Senhora das Neves do Convento Franciscano de Olinda, século XVIII. Foto: Jaqueline Silva, 2014.

Em outras ocasiões pode ter ocorrido imprevidência ao assentar os azulejos, pois nitidamente algumas peças que se desprenderam foram recolocadas aleatoriamente, até mesmo peças que não pertencem aos painéis foram utilizadas para preencher as lacunas, acarretando uma leitura difusa das cenas devido à permutação dos azulejos em sua composição (Figuras $22 \mathrm{e}$ 23). 

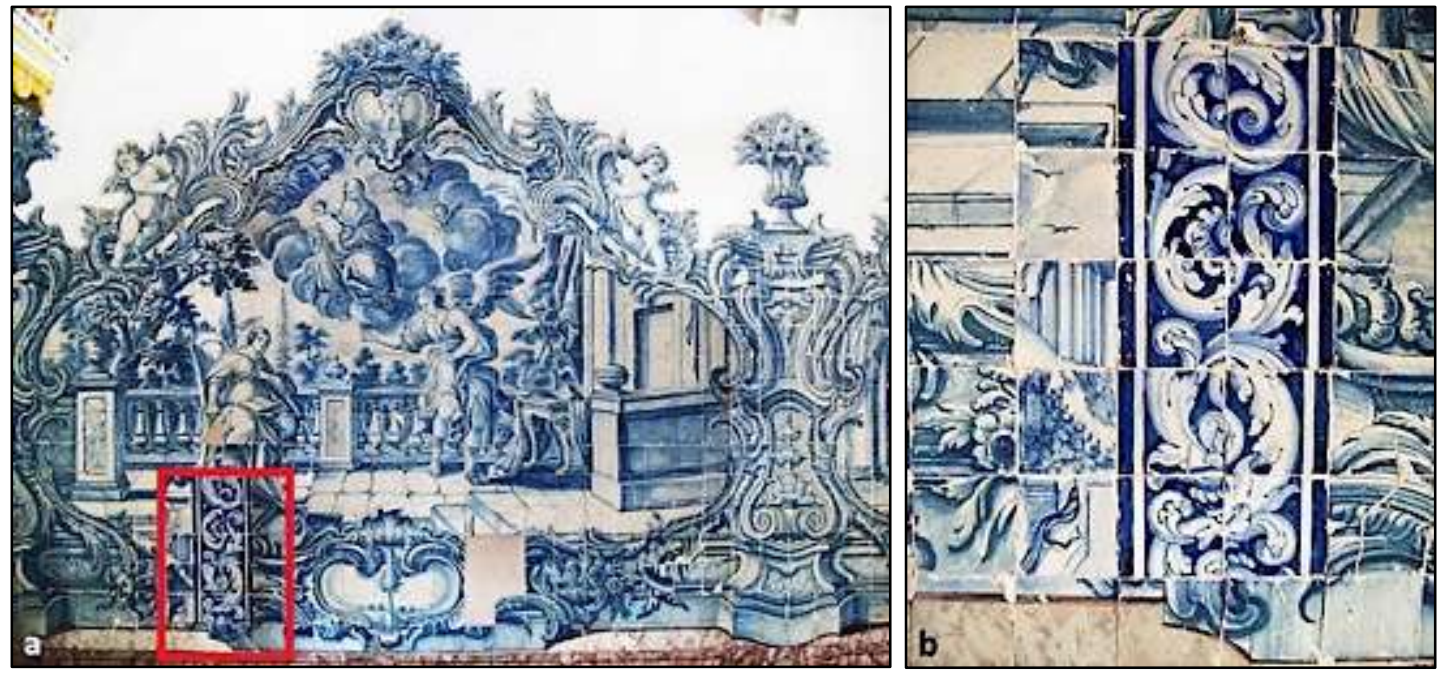

Figura 21: Painel representando anjo aparecendo a Santa Ana, com Nossa Senhora e o Menino Jesus (a) e detalhe das peças diferentes das originais (b), Capela de Santa Ana do Convento Franciscano de Olinda, século XVIII. Foto: Jaqueline Silva, 2014.
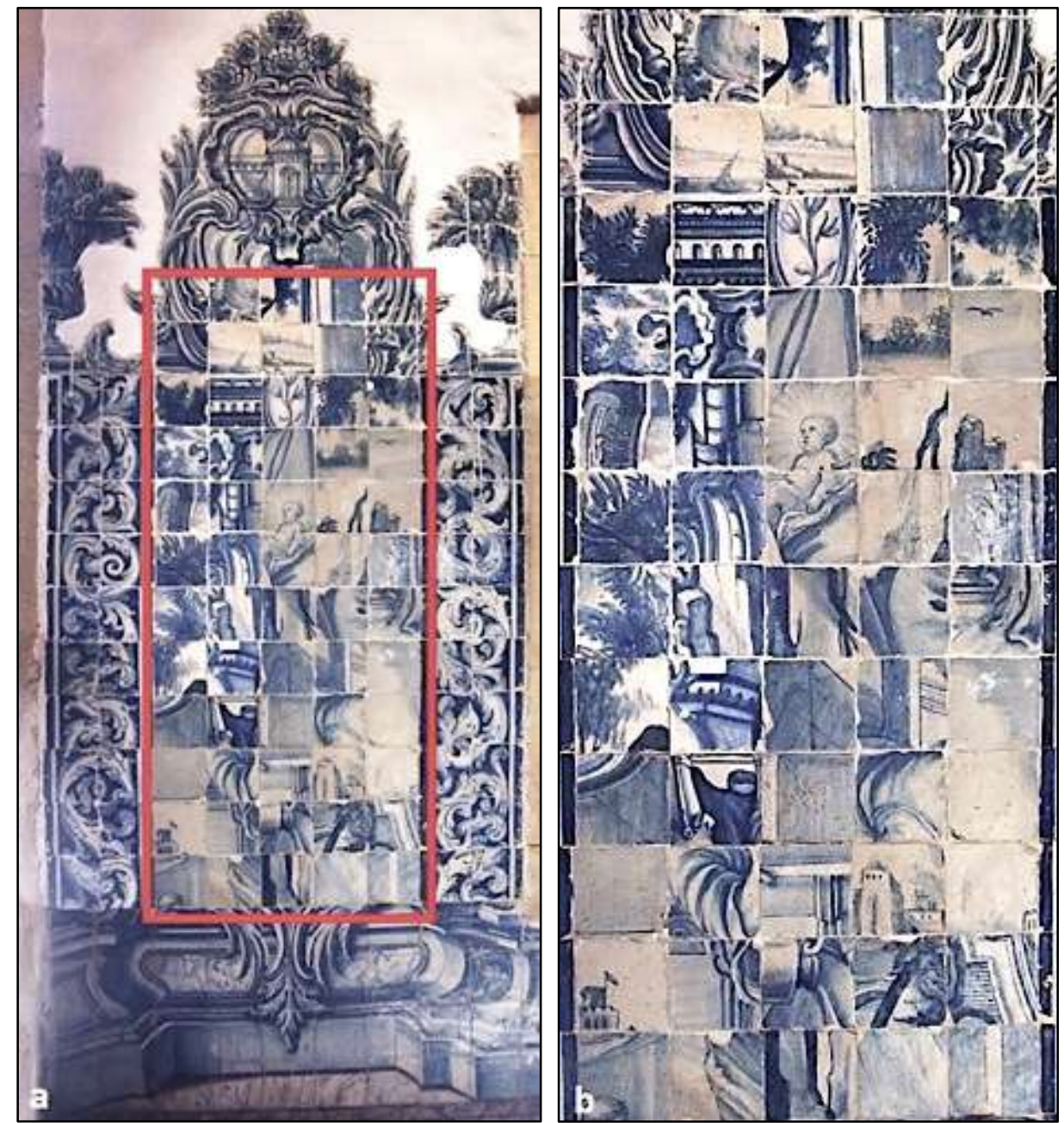

Figura 22: Painel (a) e detalhe das peças recolocadas aleatoriamente (b), Capela de Santa Ana do Convento Franciscano de Olinda, século XVIII. Foto: Jaqueline Silva, 2014. 

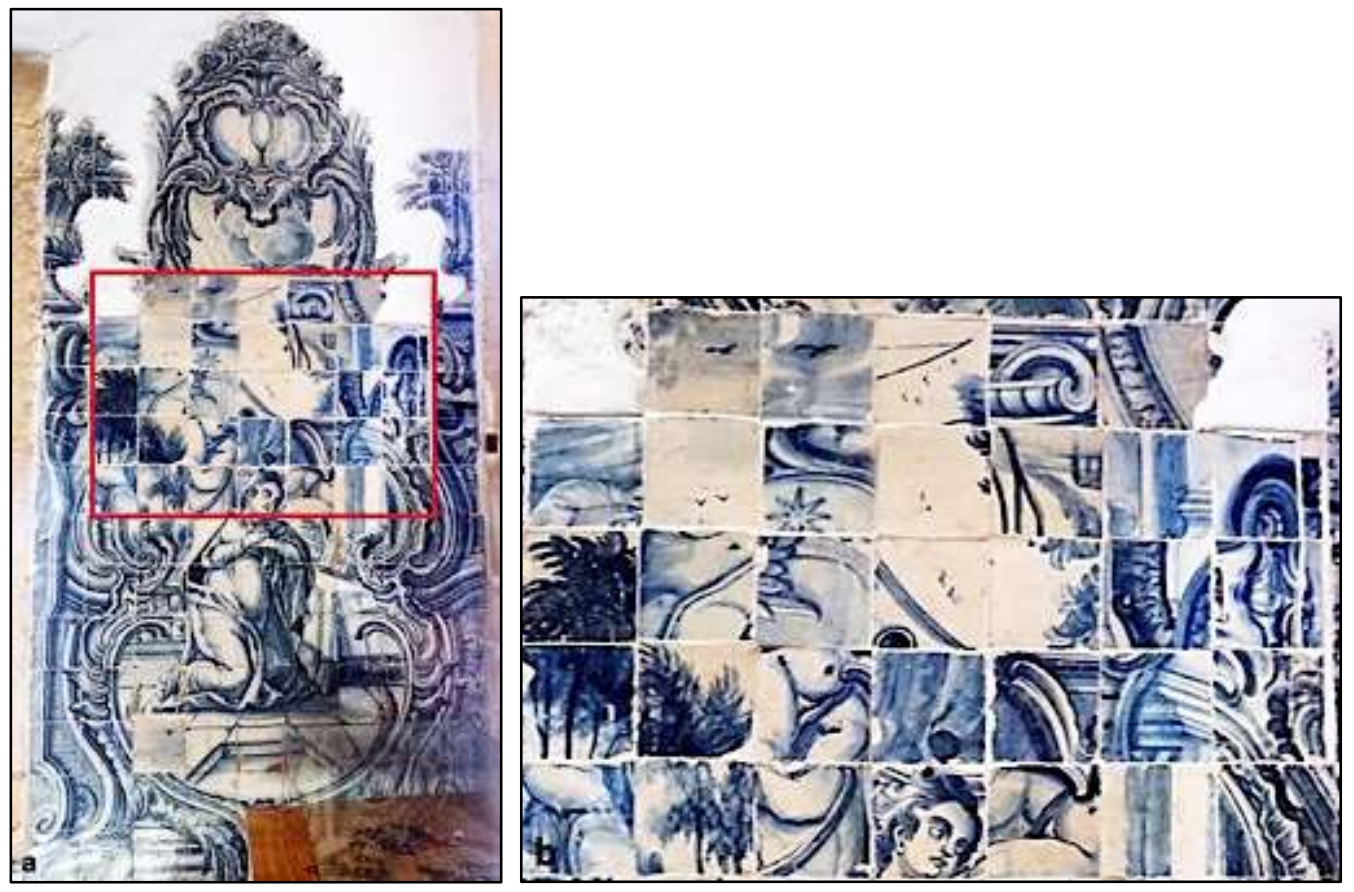

Figura 23: Painel (a) e detalhe das peças recolocadas aleatoriamente (b), Capela de Santa Ana do Convento Franciscano de Olinda, século XVIII. Foto: Jaqueline Silva, 2014.

Outra situação observada foi o desprendimento do biscoito ${ }^{9}$ (ou chacota) provocado por lesões geradas por qualquer tensão (causada por fatores internos ou externos) no suporte parietal no qual está fixado o azulejo, deixando-o vulnerável aos agentes externos degradadores, ou ainda, por furtos das peças, acarretando lacunas e descaracterização das cenas (Figuras 24 e 25).

A dilatação térmica é dos principais fatores externos que afetam os azulejos, uma vez que as variações diárias de temperatura ocasionam expansões e retrações nas peças. $O$ fator interno mais acentuado é cristalização de sais solúveis. A evaporação da água transporta os sais solúveis do interior da alvenaria para a superfície do azulejo, originando desprendimentos e eflorescências (Figura 26).

De acordo com o plano diretor de conservação, realizado pelo CECI (2006), o conjunto azulejar do Convento Franciscano de Olinda foi submetido às ações de conservação e restauro, sob a tutela do IPHAN: a primeira ocorreu em 1954, contemplando os painéis da Capela de Santa Ana e do claustro; a segunda, em 1983/84, ocorreu durante os trabalhos de consolidação das fundações da sacristia, quando todos os painéis foram desmontados, classificados e refixados. Algumas áreas cujas peças se desprenderam foram preenchidas com argamassa. Conforme Tinoco (2007), a prática utilizada era de preencher as lacunas com argamassa mista de areia e cal, somada ao cimento branco, causando incompatibilidade entre a massa de reboco nova e a primitiva (Figuras 27 e 28).

\footnotetext{
${ }^{9}$ O biscoito ou chacota é a placa de barro cozido sobre a qual é aplicado o vidrado (CALADO e PAIS, 2005: 395).
} 


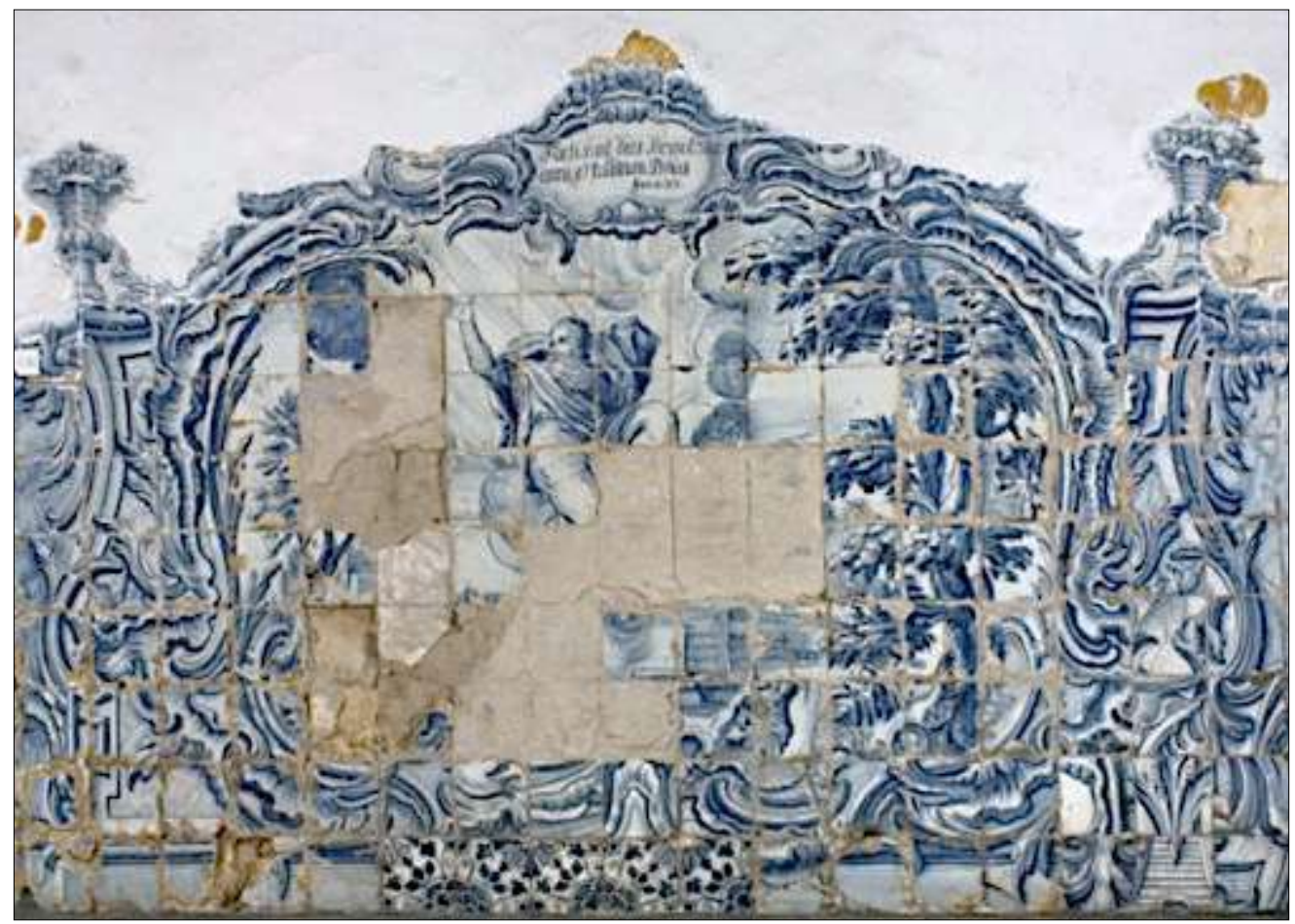

Figura 24: Painel representando Henoque com 365 anos de vida, sendo levado por Deus, apresentando desprendimento do biscoito, claustro do Convento Franciscano do Recife, século XVIII. Foto: Jaqueline Silva, 2014.

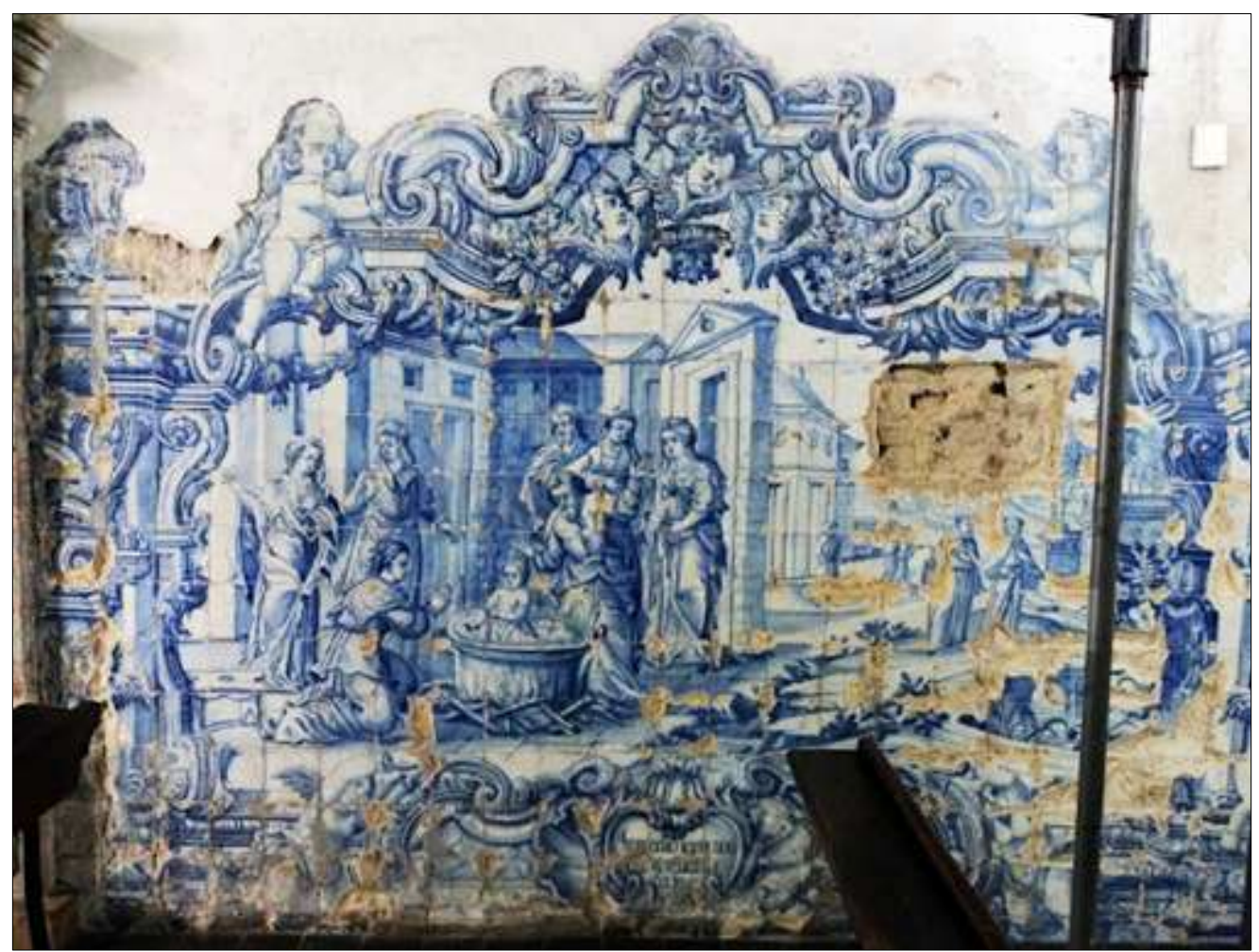

Figura 25: Painel representando um menino em uma caldeira de água fervendo, apresentando desprendimento do biscoito, Igreja de Santo Antônio do Convento Franciscano do Recife, século XVIII. Fonte: Jaqueline Silva, 2014. 

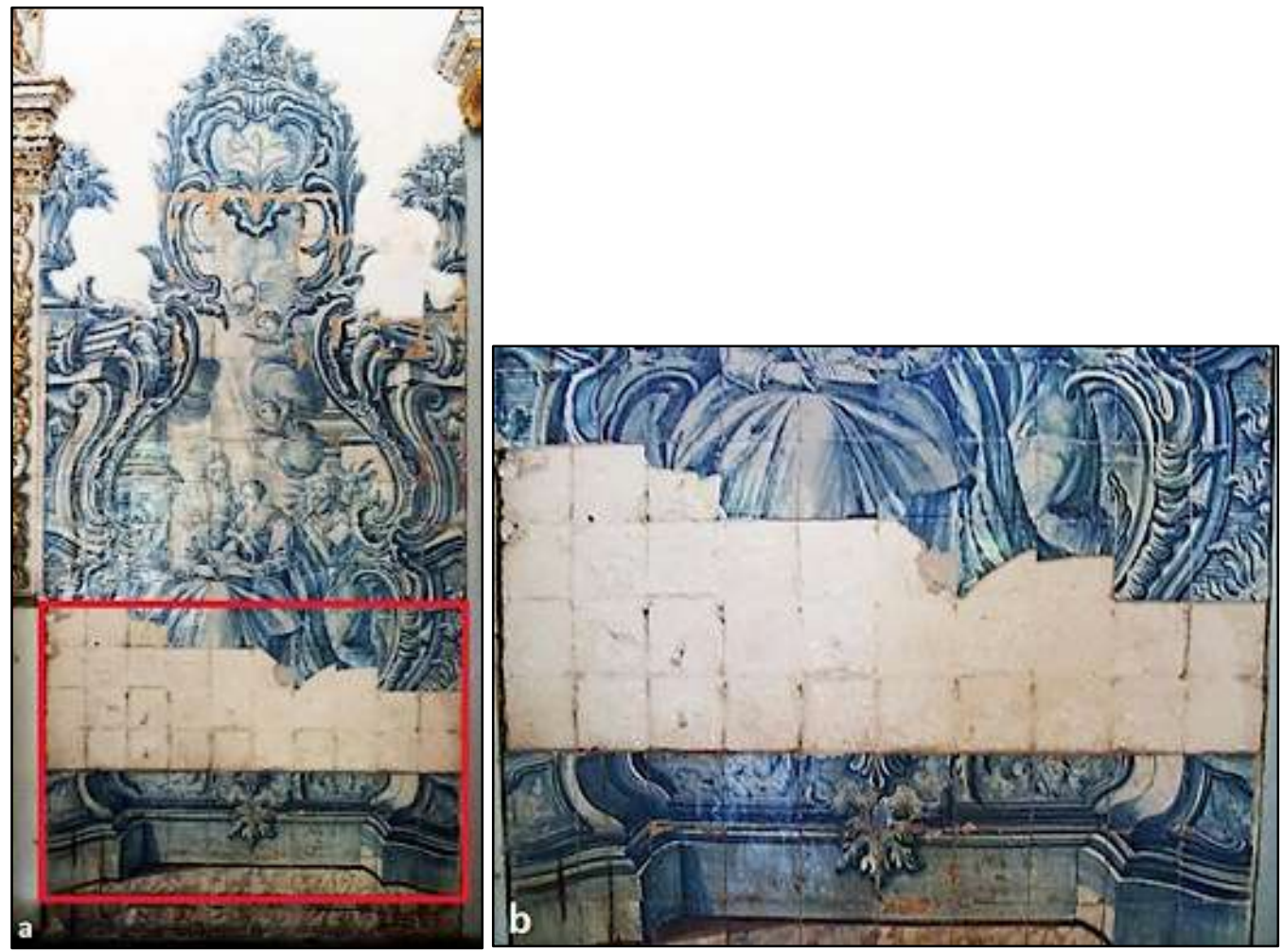

Figura 26: Painel representando Santa Ana ensinando a Virgem a ler (a) e detalhe do desprendimento do biscoito (b), Capela de Santa Ana do Convento Franciscano de Olinda, século XVIII. Foto: Jaqueline Silva, 2014.

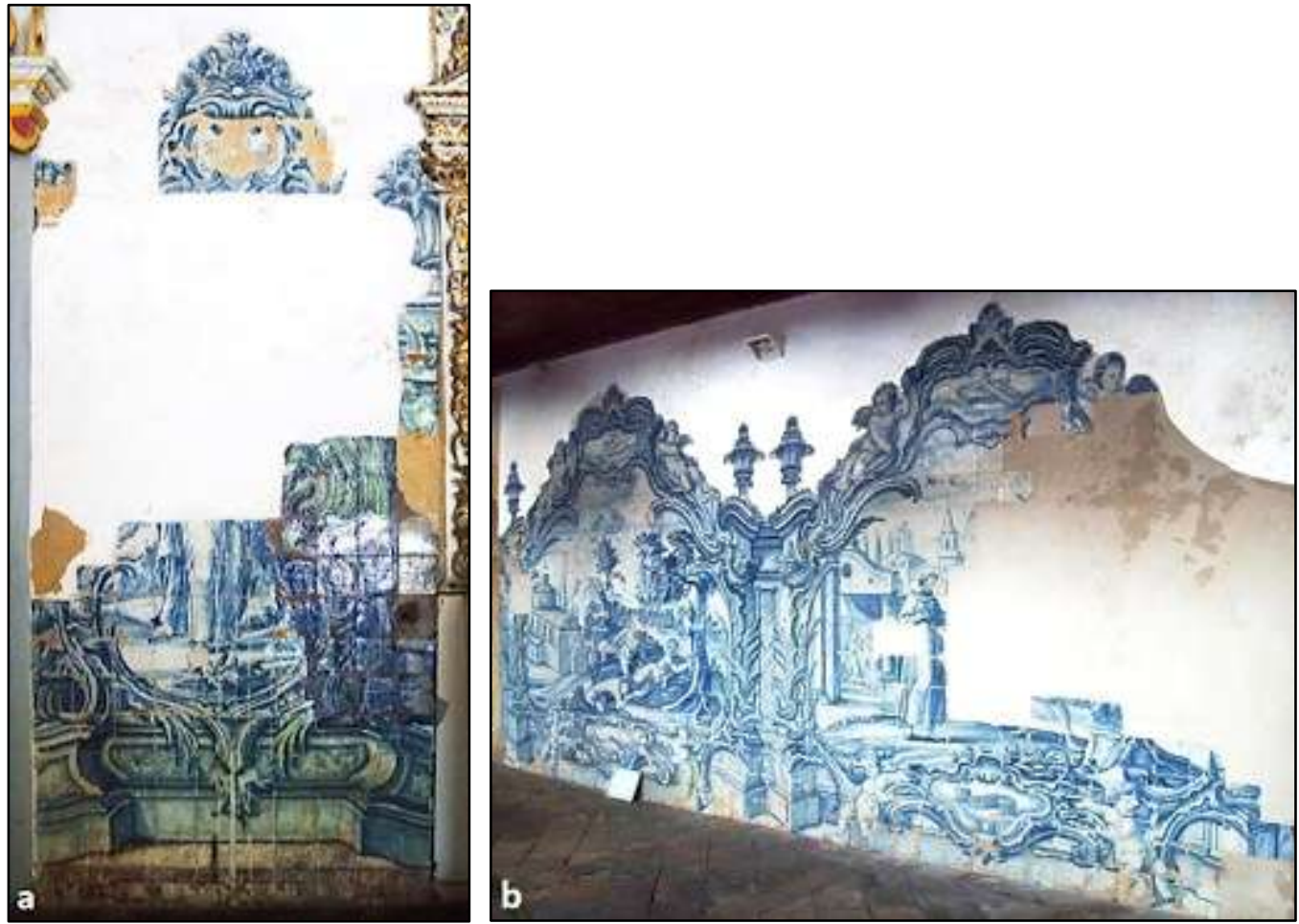

Figura 27: Painéis apresentando desprendimento do biscoito e preenchimento das lacunas com argamassa, Capela de Santa Ana (a) e claustro (b) do Convento Franciscano de Olinda, século XVIII. Foto: Jaqueline Silva, 2014. 

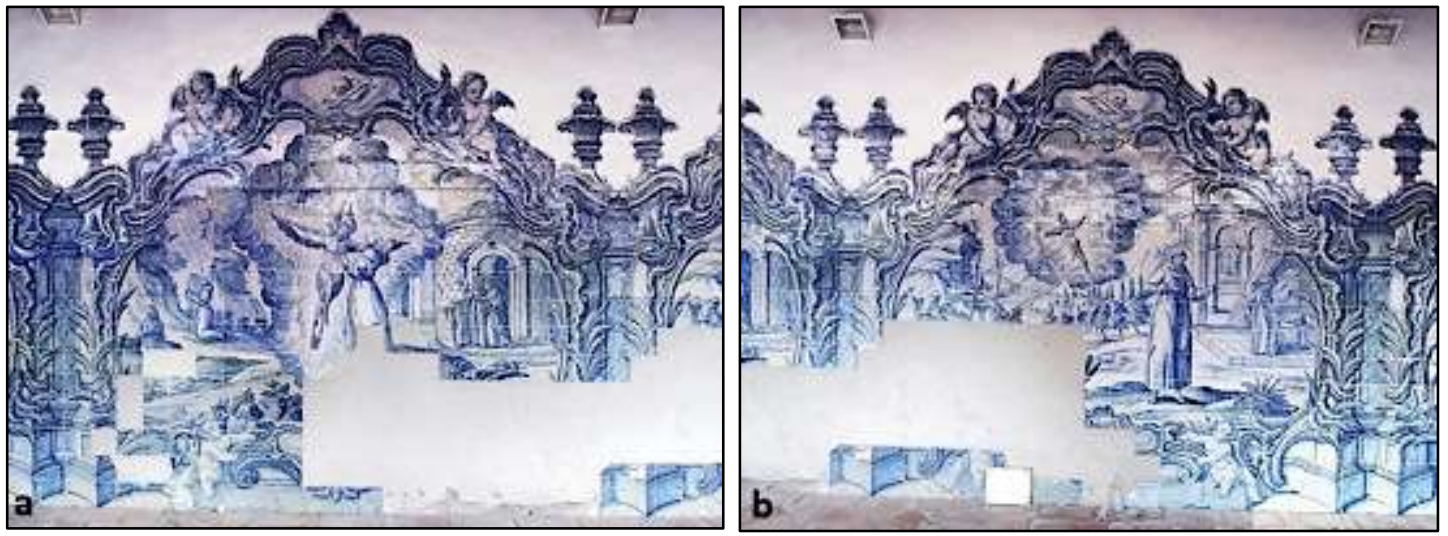

Figura 28: Painel representando São Francisco recebendo chagas de Cristo e em segundo plano abraçado a São Pedro e São Paulo (a) e painel retratando São Francisco com chagas num altar (b), ambos apresentando desprendimento do biscoito e preenchimento das lacunas com argamassa, claustro do Convento Franciscano de Olinda, século XVIII. Foto: Jaqueline Silva, 2014.

Outro fator que contribui para a impossibilidade da leitura dos painéis consiste na subtração de fileiras de azulejos que, além interferir na decoração, produz uma mistura de informações (Figuras 29 e 30).

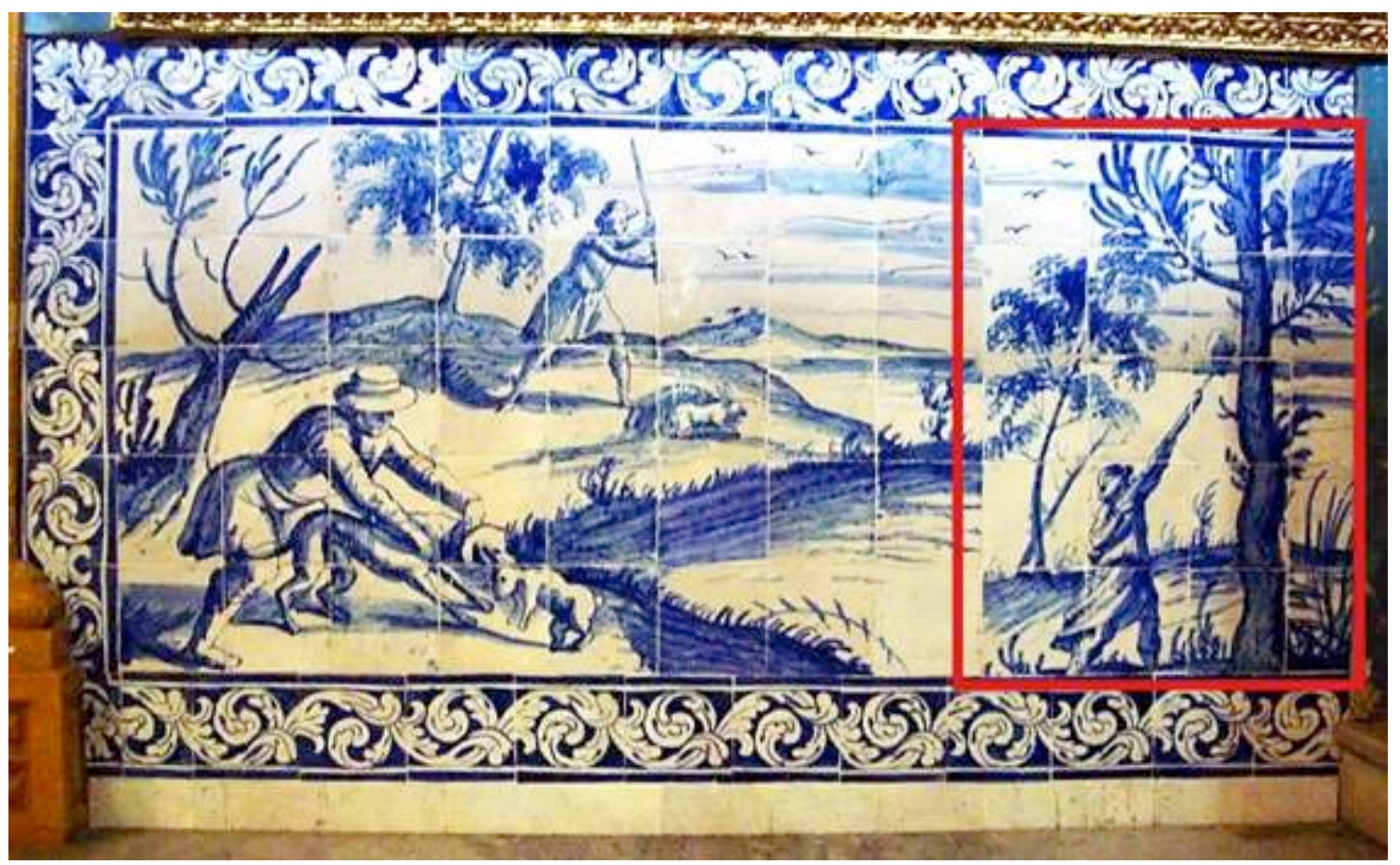

Figura 29: Painel retratando cena de caça, apresentando subtração de fileiras, Capela da Ordem Terceira do Convento Franciscano do Recife, século XVIII. Foto: Jaqueline Silva, 2014. 


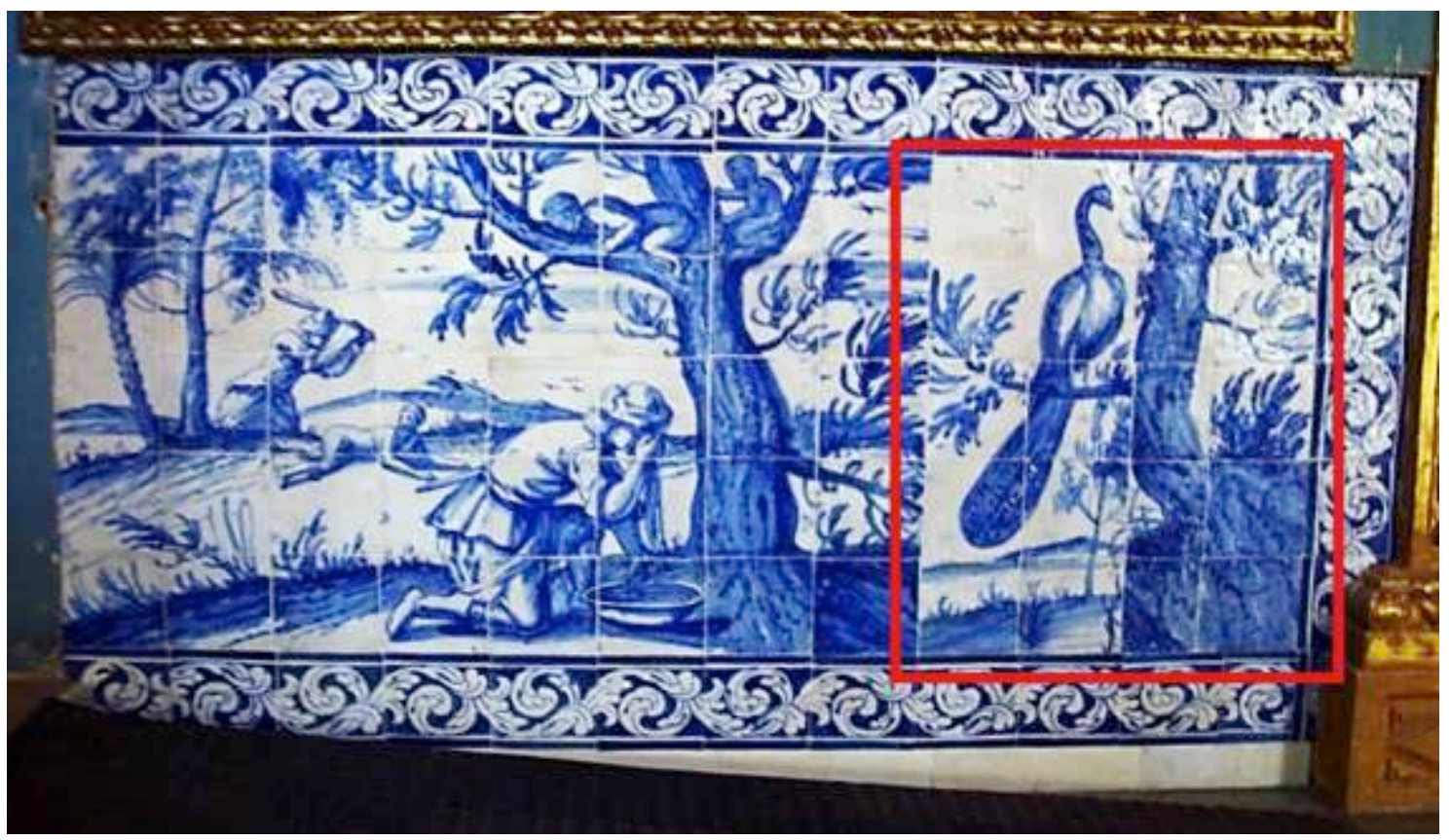

Figura 30: Painel retratando cena de caça, apresentando subtração de fileiras, Capela da Ordem Terceira do Convento Franciscano do Recife, século XVIII. Foto: Jaqueline Silva, 2014.

\section{Considerações Finais}

Através da pintura sobre o barro cozido, o azulejo representa a história e tradições de uma época de produção. Exemplo de uma arte social que encerra uma linguagem pictórica, por meio de uma narrativa histórica, que registra aspectos da cultura pernambucana. Trata-se de uma das expressões culturais mais características no campo das artes decorativas portuguesas que se infiltrou na cultura brasileira, e por sua vez, captou as características físicas e estéticas do material para ornamentar igrejas e fachadas de casas e sobrados.

No século XVII igrejas e conventos eram decorados com painéis tapetes policrômicos e monocrômicos, com padrões repetidos, adaptável a qualquer tipo de edificação. Na centúria seguinte, a policromia dos azulejos foi substituída pelos azuis de cobalto sobre fundos brancos de influência da porcelana chinesa, ganhando popularidade no Brasil.

Após semanas ou até mesmo meses, os azulejos, encaixotados e transportados nos navios, chegavam ao Brasil e eram levados aos locais destinados por meio de animais de carga. Possivelmente ocorriam acidentes, quebrando-se algumas peças, o que acarretava danos na composição dos painéis e consequentemente em sua leitura, pois cada azulejo era numerado no tardoz dando uma colocação exata para cada peça que compunha um painel. Deste modo, possivelmente, na falta desses azulejos os assentadores utilizavam peças que não correspondiam com as temáticas e figurações representadas, ou até mesmo, usavam peças e fileiras de outros painéis, gerando mistura de informação e interferência na decoração.

Outra situação identificada foi à perda do biscoito, cuja causa é a tensão sobre as alvenarias que suportam aos azulejos. Essas tensões podem ser provocadas por fatores internos ou 
externos, ocasionando desde microfissuras até o desprendimento das peças. Um fator também recorrente são os furtos, que contribui para a lacuna e descaracterização das cenas. Por fim, o assentamento inadequado dos azulejos, recolocados caoticamente e a afixação aleatória no intuito de preencher as lacunas acarretou uma desordem e tornou a leitura dos painéis difusa.

Constatou-se que os painéis azulejares dos Conventos Franciscanos de Olinda e do Recife vêm sofrendo, ao longo do tempo, com as constantes interferências naturais e/ou antrópicas, o que resulta na dificuldade de leitura das cenas, perda das características originais e deterioração das peças. Tais intervenções podem alterar os resultados de uma interpretação e análise da dimensão simbólica desse patrimônio.

O acervo azulejar que embeleza esses Conventos compõe uma página da arte extremamente significativa de própria origem e colonização portuguesa, que deve ser preservado como um patrimônio cultural brasileiro de relevante valor estético e científico. Deste modo, ressalta-se que para tornar possível a leitura desses painéis é fundamental às ações de conservação e restauro.

\section{Referências}

AGUIAR, B. C. 2009. Autenticidade e verdade: o processo de conservação do Convento de Nossa Senhora das Neves. Dissertação (Mestrado em Desenvolvimento Urbano) - Centro de Artes e Comunicação, Universidade Federal de Pernambuco, Recife.

ALARCÃO, J. 1996. Para uma conciliação das Arqueologias. Porto: Edições Afrontamento.

ALARCÃO, J. 1995. A Arqueologia como Semiologia da Cultura Material. Revista Guimarães, [s.l.], n. 105, pp. 21-41.

ALCÂNTARA, D. M. S. 2008. O azulejo: diferentes leituras. In: CORREIA, Maria Rosa (Org.). Oficinas de Estudos da Preservação. Rio de Janeiro: IPHAN. pp. 273-286.

ALMEIDA, A. 2009. Azulejaria modernista, moderna e contemporânea - curso de história do azulejo. Portugal, Dísponível em: <http://mnazulejo.imcip.pt/Data/Documents/Cursos/azulejaria_2009/AA_01.pdf>. Acesso em: 18 de jan. 2013.

BAZIN, G. 1983a. A arquitetura religiosa barroca no Brasil. Tradução Glória Lúcia Nunes. 1. ed. Rio de Janeiro: Record.

BAZIN, G. 1983b. A arquitetura religiosa barroca no Brasil. Tradução Glória Lúcia Nunes. 2. ed. Rio de Janeiro: Record.

BUENO, F. S. 1996. Minidicionário da Língua Portuguesa. São Paulo: FTD, 703.

CALADO, M.; PAIS S., Jorge H. 2005. Dicionário de Termos da Arte e Arquitectura. Lisboa: Editorial Presença. 
CÂMARA, A. G. 2009. O século XVIII. Azulejaria rococó e neoclássica. Portugal. Disponível em: <http://mnazulejo.imc-ip.pt/Data/Documents/Cursos/azulejaria_2009/agc_04.pdf>. Acesso em: 03 de mar. 2013.

CAVALCANTI, S. T. H. 2006. O azulejo na arquitetura religiosa de Pernambuco - séculos XVII e XVIII. São Paulo: Metalivros.

CAVALCANTI, S. T. H. 2002. CRUZ, Antônio de Menezes e. O azulejo na arquitetura civil de Pernambuco - século XIX. São Paulo: Metalivros.

CENTRO DE ESTUDOS AVANÇADOS DA CONSERVAÇÃO INTEGRADA. 2006. Conjunto Franciscano de Olinda - plano diretor de conservação: relatório intermediário. Olinda.

COSTA, F. A. P. da. 1951. Anais Pernambucanos. Recife: Arquivo Público Estadual, v. 1.

COSTA, F. A. P. da. 1952a. Anais Pernambucanos. Recife: Arquivo Público Estadual, v. 2.

COSTA, F. A. P. da. 1952b. Anais Pernambucanos. Recife: Arquivo Público Estadual, v. 4.

COTRIM, G. 1999. História Global: Brasil e Geral. São Paulo: Saraiva, 5ํㅡ.

DELGADO, L. 1979. O Convento de Santa Tereza em Olinda. Recife: Editora Universitária da Universidade Federal de Pernambuco.

FANNING, J. e JONES, M. 2001. A Arte e o Ofício do Azulejo. 1. ed. Lisboa: Estampa, pp. 6-9.

FLAVIAN, E.; FERNÁNDEZ, G. E. 1999. Minidicionário Espanhol-Português/Português-Espanhol. São Paulo: Editora Ática, 16ㅇed.

HENRIQUES, P. 2001. El Arte del Azulejo em Portugal. 2. ed. Lisboa: Instituto Camões / Museu Nacional do Azulejo.

MATOS, M. A. P. 2009. Azulejos: obras do Museu Nacional do Azulejo. Portugal: Chandeigne.

MECO, J. 1987. Azulejos portugueses. Lisboa: Litografia Tejo.

MELO, C. F. 2013. Técnicas de fabrico do azulejo. Portugal, 2009. Disponível em: <http://mnazulejo.imc-ip.pt/Data/Documents/Cursos/azulejaria_2009/pp_CM-2.pdf>. Acesso em: 18 de jan. 2013

MELLO, J. A. G.; SIMÕES, J. M. S. 1959. Azulejos holandeses no Convento de Santo Antônio do Recife. Recife: [s.n.], (Cadernos de Arte do Nordeste, n. 3).

MENDES, C.; VERÍSSIMO, F.; BITTAR, W. 2007. Arquitetura no Brasil: de Cabral a D. João VI. Rio de Janeiro: Imperial Novo Milênio. pp. 150-221.

MENEZES, J. L. M. 1984. Arquitetura dos Conventos Franciscanos no Nordeste. Revista do Instituto Arqueológico, Histórico e Geográfico Pernambucano, Recife, v. 57, pp. 271-282. 
MONTEIRO, J. P. 2013. Introdução à história do azulejo em Portugal. Portugal, 2009. Disponível em: $<$ http://mnazulejo.imc-ip.pt/Data/Documents/Cursos/azulejaria_2009/pp_JPM_3.pdf >. Acesso em: 03 de mar. 2013

MUELLER, F. B. O. F. M. 1956. Convento de Santo Antônio do Recife, 1606-1956: esboço histórico. Recife: Imprensa Oficial.

MUNIZ, S. C. 2009. Cronologia histórica e patologias dos azulejos em Pernambuco, entre os séculos XVII e XVIII. Dissertação (Mestrado em Arqueologia) - Centro de Filosofia e Ciências Humanas, Universidade Federal de Pernambuco, Recife.

OTT, C. 1943. Os azulejos do convento de São Francisco da Bahia. Revista do Serviço do Patrimônio Histórico e Artístico Nacional, Rio de Janeiro, n. 7, pp. 7-34, 1943.

PAIS, A. N. 2013. O século XVII. Azulejaria figurativa, de padrão e ornamental. Portugal, 2009. Disponível em: <http://mnazulejo.imc-ip.pt/Data/Documents/Cursos/azulejaria_2009/AP_01.pdf>. Acesso em 18 de jan. 2013

PINHEIRO, O. 2001. Azulejo colonial luso-brasileiro: uma leitura plural. In: TIRAPELI, Percival (Org.). Barroco memória viva: arte sacra colonial. São Paulo: Unesp, pp. 118-122.

ROMANI, D. 2011. Azulejos: Um belo patrimônio sob ameaça. Revista Continente, Recife, pp. 22-32. SIMÕES, J. M. S. 1965. Azulejaria portuguesa no Brasil 1500-1822. Lisboa: Fundação Calouste Gulbernkian.

SIMÕES, J. M. dos S. 1959. Azulejaria no Brasil - Comunicação destinada ao Colóquio de Estudos Luso-Brasileiros, na Bahia. Revista do Patrimônio Histórico e Artístico Nacional, Rio de Janeiro, n. 14, pp. 9-18.

TINOCO, J. E. L. 2007. Restauração de azulejos - recomendações básicas. Olinda: Centro de Estudos Avançados da Conservação Integrada, 15 p. n. 12. [Série Gestão de Restauro]

TONELLI, M. 2005. Arqueologia e direito: uma abordagem interdisciplinar à evidenciação de patrimônio cultural edificado. In: FUNARI, P. P. (Org.) e FOGOLARI, E. P. Estudos de Arqueologia Histórica. Erechim, pp. 59-82.

WILLEKE, F. V. O.F.M. 1956. Convento de Santo Antônio de Ipojuca. Revista do Patrimônio Histórico e Artístico Nacional, Rio de Janeiro, n. 13, pp. 255-353.

ZANCHETI, S. M.; LORETTO, R. P.; MOREIRA, F. D.; TINOCO, J. E. L. 2011. Estrutura e implantação do plano diretor de conservação do Conjunto Franciscano de Olinda. Olinda: Centro de Estudos Avançados da Conservação Integrada, 13 p. n. 51. [Série Gestão de Restauro]. 